\title{
Dopaminergic Modulation of Risk-Based Decision Making
}

\author{
Jennifer R St Onge' and Stan B Floresco*,' \\ 'Department of Psychology and Brain Research Center, University of British Columbia, Vancouver, BC, Canada
}

Psychopharmacological studies have implicated the mesolimbic dopamine (DA) system in the mediation of cost/benefit evaluations about delay or effort-related costs associated with larger rewards. However, the role of DA in risk-based decision making remains relatively unexplored. The present study investigated the effects of systemic manipulations of DA transmission on risky choice using a probabilistic discounting task. Over discrete trials, rats chose between two levers; a press on the 'small/certain' lever always delivered one reward pellet, whereas a press on the other, 'large/risky' lever delivered four pellets, but the probability of receiving reward decreased across the four trial blocks (100, 50, 25, 12.5\%). In separate groups of well-trained rats we assessed the effects of the DA releaser amphetamine, as well as receptor selective agonists and antagonists. Amphetamine consistently increased preference for the large/risky lever; an effect that was blocked or attenuated by co-administration of either $\mathrm{D}_{1}(\mathrm{SCH} 23390)$ or $\mathrm{D}_{2}$ (eticlopride) receptor antagonists. Blockade of either of these receptors alone induced risk aversion. Conversely, stimulation of D, (SKF81297) or D 2 (bromocriptine) receptors also increased risky choice. In contrast, activation of $D_{3}$ receptors with PDI28,907 reduced choice of the large/risky lever. Likewise, $\mathrm{D}_{3}$ antagonism with nafadotride potentiated the amphetamine-induced increase in risky choice. Blockade or stimulation of $\mathrm{D}_{4}$ receptors did not reliably alter behavior. These findings indicate that DA has a critical role in mediating risk-based decision making, with increased activation of $D_{1}$ and $D_{2}$ receptors biasing choice toward larger, probabilistic rewards, whereas $D_{3}$ receptors appear to exert opposing effects on this form of decision making.

Neuropsychopharmacology (2009) 34, 68I-697; doi:I0.1038/npp.2008.121; published online 30 July 2008

Keywords: $D_{2}$ receptors; amphetamine; $D_{3}$ receptors; gambling; Parkinson's disease; discounting

\section{INTRODUCTION}

Alterations in decision making involving risks and rewards have been observed with a variety of clinical disorders. In particular, individuals with disorders associated with perturbations in the dopamine (DA) system, such as schizophrenia, Parkinson's disease, and chronic amphetamine abuse, display impairments on measures of risk-based decision making, such as the Iowa and Cambridge Gambling Tasks (Rogers et al, 1999; Mimura et al, 2006). Similarly, patients with lesions on DA terminal regions, such as different regions of the prefrontal cortex or the amygdala, make risky, disadvantageous choices on these tasks (Bechara et al, 1999; Rogers et al, 1999). In keeping with these findings, acute DA depletion also leads to impaired performance on a gambling task in healthy individuals (Sevy et al, 2006).

Interest in how DA may alter risk-based decision making has increased recently in light of clinical reports linking the use of DA receptor agonists to the emergence of pathological gambling in patients with Parkinson's disease and

*Correspondence: Dr SB Floresco, Department of Psychology and Brain Research Center, University of British Columbia, 2136 West Mall, Vancouver, BC V6T IZ4, Canada, Tel: + 604827 5313, Fax: + 604 822 6923, E-mail: floresco@psych.ubc.ca

Received 30 May 2008; revised 8 July 2008; accepted I I July 2008 restless legs syndrome (Gallagher et al, 2007; Quickfall and Suchowersky, 2007). These symptoms appear to be specific to DA agonist treatment, as they are not typically observed in patients receiving levodopa monotherapy (Gallagher et al, 2007). The emergence of pathological gambling is temporally linked with the onset of DA agonist therapy, and disappears when treatment is discontinued (Imamura et al, 2006; Garcia et al, 2007), or when taken in conjunction with DA antagonists (Seedat et al, 2000). There is also evidence that DA functioning is altered in pathological gamblers without neurological disease, with decreased DA and increased DA metabolites being observed in the cerebrospinal fluid of pathological gamblers, indicative of an increase in DA neurotransmission (Bergh et al, 1997). Furthermore, acute administration of the DA releaser amphetamine to problem gamblers can increase the motivation and desire to gamble (Zack and Poulos, 2004). In a similar vein, impairments in risk-based decision making observed in clinical populations may be related to DA medication. Patients tested 'on' medication, exhibit abnormal betting strategies compared to controls (Cools et al, 2003), and have difficulty adjusting their decision strategies after negative outcomes (Frank et al, 2007), but these effects are not observed while patients are 'off' medication. Collectively, these studies suggest that increased DA activity may impair risk-based decision making, which may contribute to the emergence of pathological gambling. 
Although the above-mentioned studies suggest that DA may modulate risk-based decision making, the specific DA receptors involved in this behavior have not been identified. DA agonist medications activate $\mathrm{D}_{2}, \mathrm{D}_{3}$, and $\mathrm{D}_{4}$ receptors to varying degrees, but there is some dispute in the literature regarding which subtypes mediate their deleterious effects on decision making. Some have argued that agonists more selective for $\mathrm{D}_{3}$ receptors, such as pramipexole, are more likely to induce pathological gambling (Dodd et al, 2005; Szarfman et al, 2006), whereas others have reported that $\mathrm{D}_{1}$ / $\mathrm{D}_{2}$ receptor agonists can also promote these effects ( $\mathrm{Lu}$ et al, 2006). On the other hand, genetic studies have linked numerous DA-related genes to risky, novelty-seeking, or impulsive-addictive-compulsive behaviors. These include alterations in the Taq-A1 allele of the $D_{2}$ receptor gene (Comings et al, 1996), $\mathrm{D}_{4}$ receptors (Benjamin et al, 1996; Pérez de Castro et al, 1997; Comings et al, 2001; Li et al, 2006), $D_{1}$ receptors (Comings et al, 1997), and the DA transporter (Comings et al, 2001). However, the effects of pharmacological manipulation of these receptors on riskbased decision making have not been explored.

Studies in rodents investigating the role of DA in cost/ benefit decision making have focused on judgments related to delays or effort requirements associated with larger rewards. Blockade of DA receptors reduces the preference to either wait longer or work harder to obtain a larger reward (Cardinal et al, 2000; Salamone et al, 2001; Denk et al, 2005; van Gaalen et al, 2006). In contrast, drugs that increase DA transmission, such as amphetamine, can exert differential effects on effort- or delay-based decision making, increasing or decreasing the preference for larger rewards that come with a greater cost (Floresco et al, 2008). Yet, it is somewhat surprising that there have been very few studies investigating DA modulation of risk-based decision making. In one study, relatively high doses of amphetamine $(1-5 \mathrm{mg} / \mathrm{kg})$ induced differential effects on risky choice, although stereotypy typically induced by these doses confounds interpretation of these data (Kaminski and Ator, 2001). To explore these questions in a more detailed manner, we conducted a comprehensive study investigating how manipulations of DA transmission alter risk-based decision making in rats using a probabilistic discounting task (Cardinal and Howes, 2005). We examined the effects of the DA releaser amphetamine, as well as selective antagonists and agonists specific to $\mathrm{D}_{1}, \mathrm{D}_{2}, \mathrm{D}_{3}$, and $\mathrm{D}_{4}$ receptors on choice behavior.

\section{MATERIALS AND METHODS}

\section{Animals}

Four groups of eight male Long Evans rats (Charles River Laboratories, Montreal, Canada) weighing 275-300 g at the beginning of training were used. On arrival, rats were given 1 week to acclimatize to the colony and food restricted to $85-90 \%$ of their free feeding weight 1 week before behavioral training and given ad libitum access to water for the duration of the experiment. Feeding occurred in the rats' home cages at the end of the experimental day and body weights were monitored daily. All testing was in accordance with the Canadian Council of Animal Care and the Animal Care Committee of the University of British Columbia.

\section{Apparatus}

Behavioral testing was conducted in eight operant chambers $(30.5 \times 24 \times 21 \mathrm{~cm}$; Med-Associates, St Albans, VT, USA $)$ enclosed in sound-attenuating boxes. The boxes were equipped with a fan that provided ventilation and masked extraneous noise. Each chamber was fitted with two retractable levers, one located on each side of a central food receptacle where food reinforcement $(45 \mathrm{mg}$; Bioserv, Frenchtown, NJ) was delivered by a pellet dispenser. The chambers were illuminated by a single $100-\mathrm{mA}$ house light located in the top center of the wall opposite the levers. Four infrared photo beams were mounted on the sides of each chamber, and another photo beam was located in the food receptacle. Locomotor activity was indexed by the number of photo beam breaks that occurred during a session. All experimental data were recorded by an IBM personal computer connected to the chambers through an interface.

\section{Lever Press Training}

Our initial training protocols were adapted from those of Cardinal et al (2000). On the day before their first exposure to the operant chamber, rats were given approximately 25 food reward pellets in their home cage. On the first day of training, 2-3 pellets were delivered into the food cup and crushed pellets were placed on a lever before the animal was placed in the chamber. Rats were first trained under a fixed ratio 1 schedule to a criterion of 60 presses in $30 \mathrm{~min}$, first for one lever, and then repeated for the other lever (counterbalanced left/right between subjects). They were then trained on a simplified version of the full task. These 90 trial sessions began with the levers retracted and the operant chamber in darkness. Every $40 \mathrm{~s}$, a trial was initiated with the illumination of the house light and the insertion of one of the two levers into the chamber. If the rat failed to respond on the lever within $10 \mathrm{~s}$, the lever was retracted, the chamber darkened and the trial was scored as an omission. If the rat responded within $10 \mathrm{~s}$, the lever retracted and a single pellet was delivered with 50\% probability. This procedure was used to familiarize the rats to the probabilistic nature of the full task. In every pair of trials, the left or right lever was presented once, and the order within the pair of trials was random. Rats were trained for approximately 5-6 days to a criterion of 80 or more successful trials (ie $\leqslant 10$ omissions).

\section{Risk Discounting Task}

The task was modified from procedures described by Cardinal and Howes (2005) and is illustrated in Figure 1a. Rats received daily sessions consisting of 72 trials, separated into four blocks of 18 trials. The entire session took $48 \mathrm{~min}$ to complete, and the animals were trained 6-7 days per week. A session began in darkness with both levers retracted (the intertrial state). A trial began every $40 \mathrm{~s}$ with the illumination of the house light and insertion of one or both levers into the chamber (the format of a single trial is shown in Figure 1b). One lever was designated the 
a

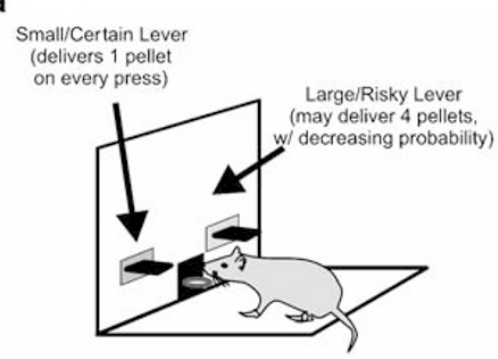

C

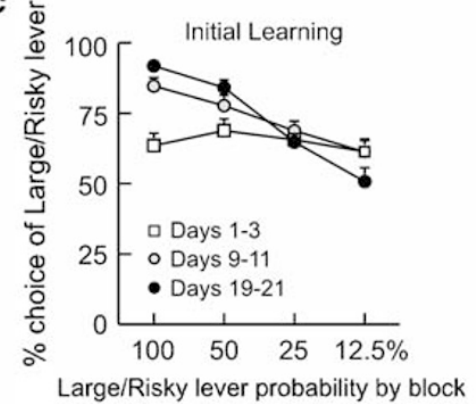

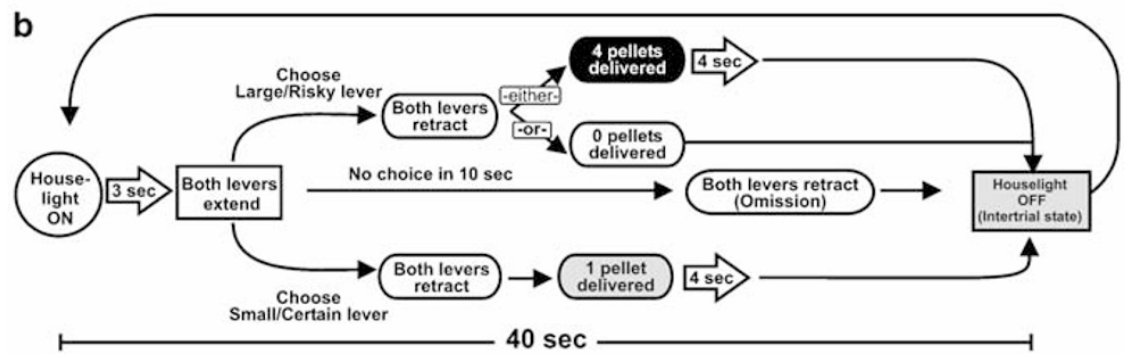

Figure I Schematic of the risk discounting task. (a) Cost/benefit contingencies associated with responding on either the small/certain or large/risky lever on the risk discounting task. (b) The format of a single free-choice trial on the risk discounting task. (c) Mean (+ SEM) proportion of choices of the large/risky lever across the four trial blocks for all animals at different time points in training.

large/risky lever, the other the small/certain lever, which remained consistent throughout training (counterbalanced left/right). If the rat did not respond within $10 \mathrm{~s}$ of lever presentation, the chamber was reset to the intertrial state until the next trial (omission). When a lever was chosen, both levers retracted. Choice of the small/certain lever always delivered one pellet with $100 \%$ probability; choice of the large/risky lever delivered four pellets but with a particular probability (see below). After a response was made and food delivered, the house light remained on for another $4 \mathrm{~s}$, after which the chamber reverted back to the intertrial state until the next trial. Multiple pellets were delivered $0.5 \mathrm{~s}$ apart. The large reinforcer probability was varied systematically across the session as follows. The 4 blocks were consisting of eight forced choice trials where only one lever was presented (four trials for each lever, randomized in pairs) permitting animals to learn the amount of food associated with each lever press and the respective probability of receiving reinforcement over each block. This was followed by 10 free-choice trials, where both levers were presented and the animal had to decide whether to choose the small/certain or the large/risky lever. The probability of obtaining four pellets after pressing the large/ risky lever varied across the four blocks: it was initially $100 \%$, then 50,25 , and $12.5 \%$, respectively. Rats were trained on the task until as a group, they (1) chose the large/ risky lever during the first trial block ( $100 \%$ probability) on at least $80 \%$ of successful trials and (2) demonstrated stable baseline levels of choice. Drug tests were administered after a group of rats displayed stable patterns of choice for 3 consecutive days, assessed using a procedure similar to that described by Winstanley et al (2005) and Floresco et al (2008). In brief, data from three consecutive sessions were analyzed with a repeated measures ANOVA with two within-subjects factors (day and trial block). If the effect of block was significant at the $P<0.05$ level but there was no main effect of day or day $\times$ block interaction (at $P>0.1$ level), animals were judged to have achieved stable baseline levels of choice behavior.

\section{Pharmacological Manipulations}

We used a within-subjects design for all drug tests. Each test consisted of a two day sequence in which animals received intraperitoneal vehicle (day 1) and then drug (day 2) injections $10-40 \mathrm{~min}$ before a daily training session. These repeated vehicle tests compensated for any drift in baseline levels of choice that may have occurred over training (see Results). Following a drug test day, rats were retrained until they again displayed stable patterns of choice, after which subsequent drug tests were administered (approximately another 3-5 days of training). This procedure was repeated until rats in a group had received each of their designated treatments.

\section{Drugs and Satiety Manipulations}

The following drugs were used. DA agonists: D-amphetamine (Sigma-Aldrich, Oakville, Ontario, Canada), the $\mathrm{D}_{1}$ receptor agonist SKF81297 (Tocris Biosciences, Ellisville, Missouri), the $\mathrm{D}_{2}$ agonist bromocriptine (Sigma-Aldrich), the $\mathrm{D}_{3}$ agonist PD128,907 (Tocris) and the $\mathrm{D}_{4}$ agonist PD168,077 (Tocris). DA antagonists included: the $\mathrm{D}_{1}$ antagonist SCH23390 hydrochloride (Sigma-Aldrich), the $\mathrm{D}_{2}$ antagonist eticlopride hydrochloride (Sigma-Aldrich), the $\mathrm{D}_{3}$ antagonist nafadotride (Tocris), and the $\mathrm{D}_{4}$ antagonist L745,870 (Tocris).

All drugs were dissolved in $0.9 \%$ saline, sonicated until dissolved, and protected from light, with the exception of bromocriptine and nafadotride, which were first dissolved in dimethyl sulfoxide and then diluted with saline in a 50:50 ratio. All drug doses were calculated as salt weights. 
Drugs were injected intraperitoneally at a volume of $1 \mathrm{ml} / \mathrm{kg}$ either $10 \mathrm{~min}$ (amphetamine, SKF81297, PD128,907, PD168,077), $20 \mathrm{~min}$ (DA antagonists), or $40 \mathrm{~min}$ (bromocriptine) before testing. With drug combinations, the antagonist was administered $20 \mathrm{~min}$ before and amphetamine $10 \mathrm{~min}$ before testing. Drug tests were separated by at least 3 days.

Drug doses for amphetamine, and the $D_{1}, D_{2}$, and $D_{4}$ antagonists were chosen from previous studies reporting alterations in cognitive functioning, including working memory, and other forms of cost/benefit decision making (Cardinal et al, 2000; Zhang et al, 2004; van Gaalen et al, 2006; Floresco et al, 2008). Doses of the $D_{1}$ (SKF81297) and $\mathrm{D}_{4}$ (PD168,077) agonists have been shown to alter memory performance after systemic administration (Browman et al, 2005; Hotte et al, 2005) and have high selectivity in vivo (Bitner et al, 2006; Gleason and Witkin, 2006). Bromocriptine is 10 and 100 times more potent at $D_{2}$ receptors vs $D_{3}$ and $\mathrm{D}_{4}$ receptors, respectively (Seeman and Van Tol, 1993; Perachon et al, 1999), and is behaviorally active at $5.0 \mathrm{mg} / \mathrm{kg}$ (Kelsey and Carlezon, 2002). Nafadotride has approximately 10-20 times greater affinity for $\mathrm{D}_{3}$ vs $\mathrm{D}_{2}$ receptors (Griffon et al, 1995) but may only be selective at $D_{3}$ receptors at doses under $2.0 \mathrm{mg} / \mathrm{kg}$ (Levant and Vansell, 1997). Finally, the $\mathrm{D}_{3}$ agonist $\mathrm{PD} 128,907$ has higher selectivity for $\mathrm{D}_{3}$ receptors vs $\mathrm{D}_{2}$ and $\mathrm{D}_{4}$ receptors (Bristow et al, 1996) and is behaviorally active at $\mathrm{D}_{3}$ receptors between 0.10 and $0.50 \mathrm{mg} / \mathrm{kg}$ (Collins et al, 2005).

The specific pharmacological manipulations that rats in each of the four groups were subjected to are summarized in Table 1. Separate groups of rats were used for experiments using DA antagonists $v s$ the DA receptor agonists. For group $\mathrm{AMPH}$, the drugs were given in the following order: amphetamine, SCH23390, SCH23390 + amphetamine, eticlopride, and eticlopride + amphetamine. Group D1/4 received three doses each of SKF81297 and PD168,077.

Table I Experiments Performed

\begin{tabular}{ll}
\hline Group & Manipulation (dose, order administered) \\
\hline AMPH & D-amphetamine $(0.50,0.25,0.125,1.0 \mathrm{mg} / \mathrm{kg})$ \\
& SCH23390 $(0.01,0.005 \mathrm{mg} / \mathrm{kg})$ \\
& $\mathrm{SCH} 23390(0.01 \mathrm{mg} / \mathrm{kg})+\mathrm{amphetamine}(0.50 \mathrm{mg} / \mathrm{kg})$ \\
& Eticlopride $(0.03,0.01 \mathrm{mg} / \mathrm{kg})$ \\
& Eticlopride $(0.01 \mathrm{mg} / \mathrm{kg})+\mathrm{amphetamine}(0.50 \mathrm{mg} / \mathrm{kg})$ \\
& SKF8I297 $(0.30,0.10,1.0 \mathrm{mg} / \mathrm{kg})$ \\
DI/4 & PDI68,077 $(1.0,5.0,0.50 \mathrm{mg} / \mathrm{kg})$ \\
& Acute free feeding \\
& Long-term free feeding \\
& L745,870 $(5.0,1.0,0.50 \mathrm{mg} / \mathrm{kg})$ \\
& L745,870 $(5.0 \mathrm{mg} / \mathrm{kg})+\mathrm{amphetamine}(0.50 \mathrm{mg} / \mathrm{kg})$ \\
& Nafadotride $(2.0,1.0,0.5 \mathrm{mg} / \mathrm{kg})$ \\
& Nafadotride $(0.50 \mathrm{mg} / \mathrm{kg})+\mathrm{amphetamine}(0.50 \mathrm{mg} / \mathrm{kg})$ \\
& Bromocriptine $(5.0,1.0 \mathrm{mg} / \mathrm{kg})$ \\
& PDI28,907 $(0.10,0.50,0.25 \mathrm{mg} / \mathrm{kg})$ \\
& Acute free feeding \\
& Long-term free feeding \\
&
\end{tabular}

Group D3/4 received L745,870, L745,870 + amphetamine, nafadotride, nafadotride + amphetamine and group D2/3 received bromocriptine and $\mathrm{PD} 128,907$.

After the animals in groups D1/4 and D2/3 had completed all drug tests, satiety tests were given to establish the effect of varying motivational state on preference for probabilistic reinforcement. Following the last set of tests, these groups were retrained until their choice pattern was again stable, after which they were given ad-libitum access to lab chow in their home cage for six days. For the combined data from the two groups, average choice across blocks from the last three days of food restriction was compared to the first day of free feeding (acute free feed), as well as to the last three days of free feeding (long-term free feed).

\section{Data Analysis}

The primary dependent measure of interest was the percentage of choices directed toward the large/risky lever for each block of free-choice trials, factoring in trial omissions (an index of risky choice). For each block, this was calculated by dividing the number of choices of the large/risky lever by the total number of successful trials. With all choice data, the main effect of block was always significant $(P<0.05)$ indicating that rats were discounting as expected (choosing the large/risky lever less as the probability of the large reward decreased across the four blocks). For each series of drug tests with amphetamine, the agonists, or the antagonists on their own, the choice data were subjected to separate three-way, repeated measures ANOVAs with dose, test day (vehicle or drug) and trial block as within-subject factors. Whenever there was an interaction with or a main effect of test day, the data from the drug test was compared to those obtained after the vehicle injection that directly preceded it. When amphetamine was combined with a DA receptor antagonist, choice data were analyzed with two-way, repeated measures ANOVAs with test day (amphetamine, amphetamine + antagonist, or vehicle) and trial block as within-subject factors, where we used an average of the data for the two vehicle tests associated with the preceding amphetamine and the amphetamine + antagonist drug test. The latencies to respond across trial blocks were analyzed in a similar manner to choice. Locomotor activity (ie photo beam breaks) and the number of trial omissions were analyzed with one-way repeated measures ANOVAs, where data from multiple vehicle tests were averaged. The results of the statistical analyses of these data are only reported when a significant difference was observed. The effects of satiety on behavioral measures were analyzed using two-way, repeated measures ANOVAs with day (food restriction, acute free feed, long-term free feed) and trial block as within-subject factors. Missing values were replaced with the group mean. Dunnett's or Tukey's tests were used for multiple comparisons where appropriate.

\section{RESULTS}

\section{Acquisition of the Risk Discounting Task}

Initial training. Rats in all four groups demonstrated sensitivity to decreasing probabilities of the larger reward 
and stable baseline levels of choice behavior after an average of $25 \pm 3$ days of training on the risk discounting task (group $\mathrm{AMPH}=21$, group $\mathrm{D} 1 / 4=30$, group $\mathrm{D} 2 / 3=20$, group $\mathrm{D} 3 / 4=30$ days). Changes in the preference of the large/risky lever that occurred over training for all 32 rats are shown in Figure 1c. During the first 3 days of training, rats displayed a slight preference for the large/risky lever that was comparable across trial blocks. By training sessions 9-11, a preference for the large/risky lever emerged during the first trial block. Moreover, rats began to display a discounting curve over the course of the session, choosing this lever less as the probability of delivery of the larger reward decreased. By sessions 19-21, rats were choosing this lever on over $90 \%$ of trials during the first block, and displayed a steeper discounting curve over the rest of the session. It is notable that within each cohort of rats, as well as across groups, there was considerable variability in baseline levels of choice, where some rats (and some groups) were more 'risky' in the latter trial blocks, where others displayed a greater preference for smaller/certain rewards. We also observed that, over extended training, the discounting curve of a group tended to 'sharpen', with rats showing increased preference for the large/risky lever in the $50 \%$ block (ie an advantageous choice) and decreased preference in the last block. This is presumably because rats had acquired more experience with the overall magnitude of reward that could be obtained over these blocks if rats chose risky or safe.

\section{Effects of Amphetamine on Risk Discounting}

Over several weeks, rats in group AMPH received four doses of amphetamine (Table 1). Analysis of the choice data revealed a significant main effect of test day $(\mathrm{F}(1,7)=10.68$, $P<0.05)$ and a significant test day $\times$ block interaction $(\mathrm{F}(3,21)=4.07, P<0.05)$. The dose $\times$ test day $\times$ block interaction only approached statistical significance $(\mathrm{F}(9,63)=1.95, P=0.06)$, likely because the $0.125 \mathrm{mg} / \mathrm{kg}$ dose was not as effective at increasing risky choice on the latter trial blocks. On average, all doses of amphetamine increased choice of the large/risky lever compared to saline (Dunnett's, $P<0.05$; Figure 2e). These increases were significantly higher on the 25 and $12.5 \%$ trial block, reflecting a disadvantageous pattern of choice. Although no dose of amphetamine was significantly more effective than the other doses, the $0.50 \mathrm{mg} / \mathrm{kg}$ dose promoted the largest increase in risky choice across the last three blocks and did not significantly increase response latencies or trial omissions. Therefore, this dose of amphetamine was used in subsequent drug test combinations with the DA antagonists. Latencies to choose between the large/risky and small/ certain levers were only affected by the $1.0 \mathrm{mg} / \mathrm{kg}$ dose of amphetamine as indicated by a dose $\times$ test day interaction $(\mathrm{F}(3,21)=3.15, P<0.05$, Dunnett's, $P<0.05$; Table 2). As expected, locomotor activity was increased by the $0.25,0.50$, and $1.0 \mathrm{mg} / \mathrm{kg}$ doses of amphetamine relative to saline $(\mathrm{F}(3,21)=21.56, P<0.001$ and Dunnett's, $P<0.05$; Table 2$)$. Thus, increasing DA release with amphetamine increases the preference for larger rewards that come with a greater risk.

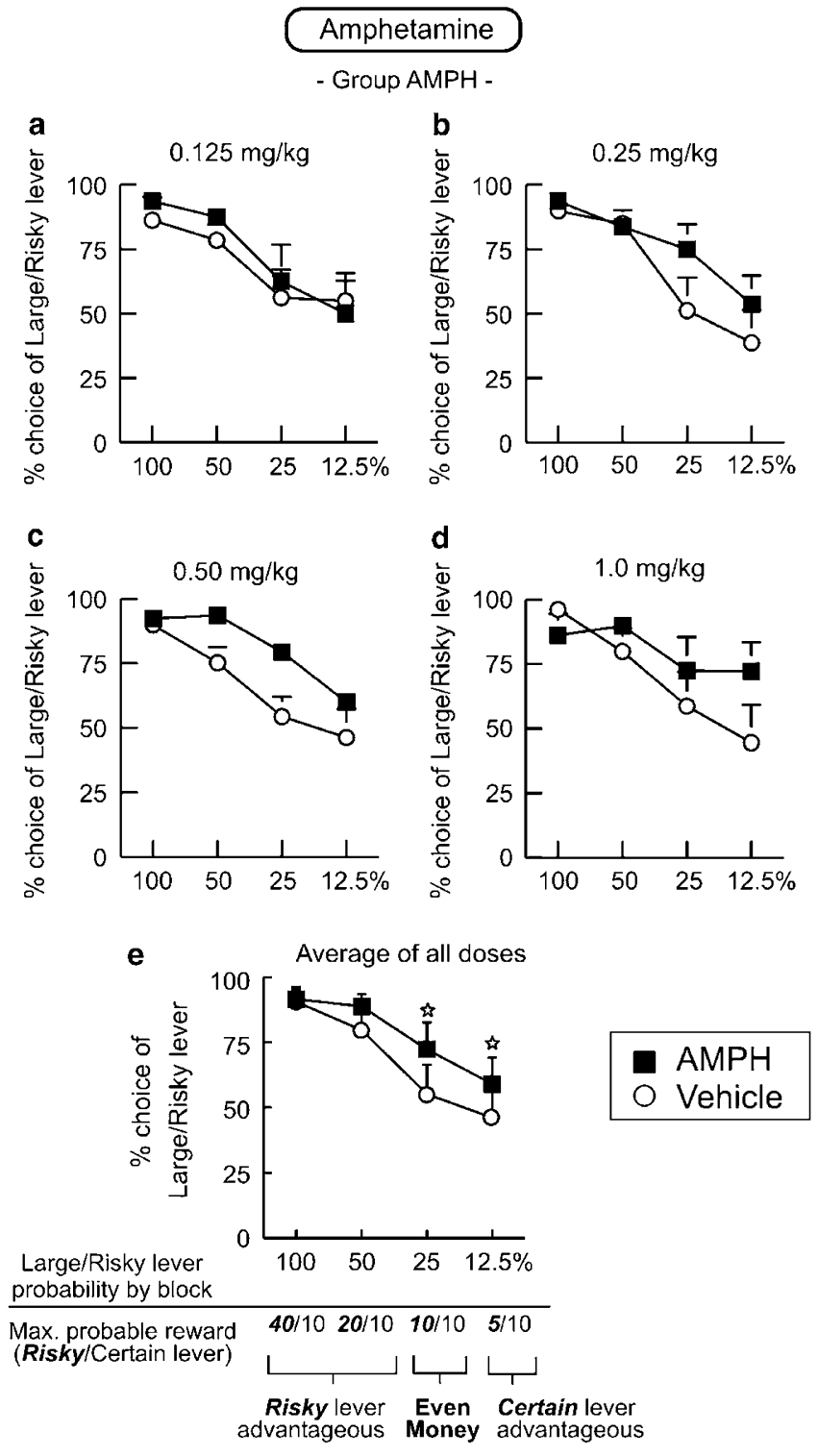

Figure 2 The effects of amphetamine (AMPH) on risk-based decision making. Percentage choice for the large/risky lever ( $y$ axis) is plotted as a function of the large/risky lever probability by block ( $x$ axis). Symbols represent mean \pm SEM. Stars denote significant $(P<0.05)$ differences vs vehicle at a specific block. (a-d) The effects of the $0.125,0.25,0.5$, and $1.0 \mathrm{mg} / \mathrm{kg}$ doses of $\mathrm{AMPH}$, respectively. The latter three doses induced a reliable and robust increase in the proportion of choices of the large/risky lever. (e) Comparison of percentage choice of the large/risky lever averaged across all vehicle tests compared to the average percentage choice of all AMPH challenges. For this and all subsequent figures, the vehicle data is an average of all those vehicle tests that were administered immediately before the drug tests presented in the particular figure. The $x$ axis denotes odds of receiving the large reward after choosing the Risky lever over the four trial blocks (top), and the maximal reward that could be obtained (on average) in each block if the rat responded exclusively on the Risky or Certain lever (bottom).

\section{$\mathrm{D}_{1}$ Receptor Compounds}

Blockade with SCH23390. Following tests with amphetamine, rats in group AMPH were retrained until performance was stable and subsequently administered two doses of SCH23390 on separate test days (Table 1). This analysis 
Table 2 Response Latency, Locomotion, Trial Omissions for amphetamine, D, and $D_{2}$ Receptor Compounds

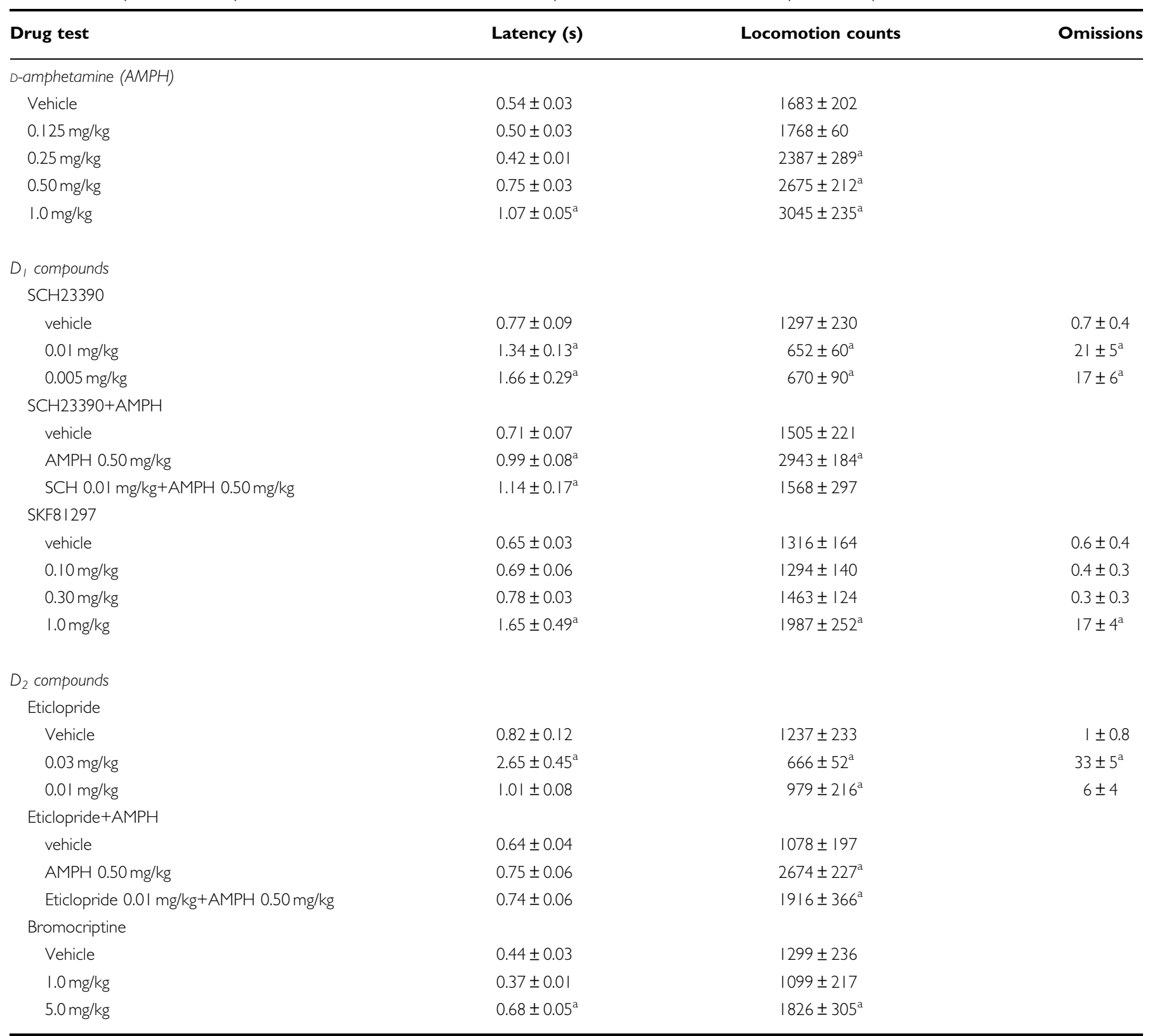

${ }^{\mathrm{a} P}<0.05$ vs vehicle.

revealed a significant dose $\times$ test day $\times$ block interaction $(\mathrm{F}(3,21)=4.27, P<0.05$, Dunnett's, $P<0.05$; Figure 3a). The $0.01 \mathrm{mg} / \mathrm{kg}$ dose significantly decreased choice of the large/ risky lever across all trial blocks, including the $100 \%$ trial block, indicating a disruption in discriminating between small and large rewards. Yet, the $0.005 \mathrm{mg} / \mathrm{kg}$ dose of SCH23390 did not alter discrimination on the $100 \%$ trial block, but did significantly $(P<0.05)$ decrease preference for the large/risky lever on the 50 and $25 \%$ trial blocks compared to saline. Treatment with SCH23390 significantly increased the number of trial omissions relative to saline $(\mathrm{F}(2,7)=7.18, P<0.01$; Table 2). Analysis of the response latency data revealed a significant main effect of test day $(\mathrm{F}(1,7)=37.28, P<0.01$; Table 2$)$. Both doses of SCH23390 increased choice latencies, and decreased locomotor counts
$(\mathrm{F}(2,14)=7.78, P<0.01 ;$ Table 2$)$. Thus, systemic blockade of $\mathrm{D}_{1}$ receptors induces risk aversion, with animals shifting their preference for smaller but more reliable rewards.

Amphetamine + SCH23390. After receiving challenge doses of SCH23390, rats in group AMPH received combinations of the $0.01 \mathrm{mg} / \mathrm{kg}$ dose of SCH 23390 and the $0.50 \mathrm{mg} / \mathrm{kg}$ dose of amphetamine. These data yielded a significant test day $\times$ block interaction $(\mathrm{F}(6,42)=2.79, P<0.05$, Dunnett's, $P<0.05$; Figure $3 b$ ). As was previously observed with this group, amphetamine again increased the proportion of choices of the large/risky lever on the last three blocks $(P<0.05)$. However, pretreating the animals with SCH23390 abolished this effect. Analysis of the response latency data indicated a test day $\times$ block interaction $(F(6,42)=2.86$, 
D1 Antagonist $(\mathrm{mg} / \mathrm{kg})$

- Group AMPH -
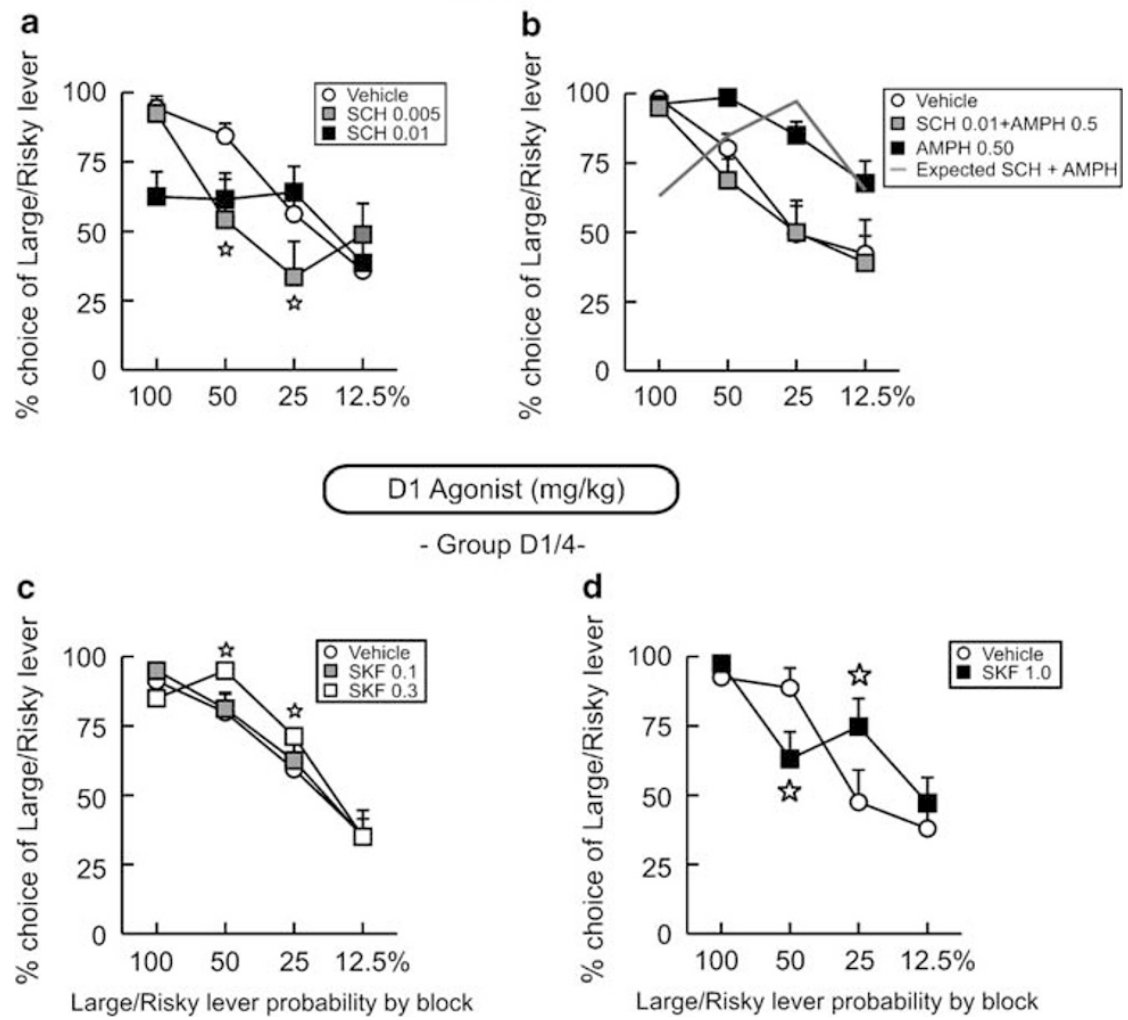

Figure 3 The effects of $D_{1}$ receptor manipulations on risk-based decision making. All other conventions are the same as Figure 2. (a) $D_{1}$ receptor blockade with $\mathrm{SCH} 23390$. A high dose $(0.01 \mathrm{mg} / \mathrm{kg}$ ) disrupted discrimination between small and large rewards, whereas a low dose $(0.005 \mathrm{mg} / \mathrm{kg})$ that did not disrupt discrimination during the first block decreased the proportion of choices of the large/risky lever in the middle two blocks. (b) SCH23390 + amphetamine. Blockade of $D_{1}$ receptors $(0.01 \mathrm{mg} / \mathrm{kg}$ ) before the administration of amphetamine completely blocked the increased proportion of choices of the large/risky lever induced by amphetamine alone. The gray line represents an 'expected' discounting curve determined by subtracting the effects of $\mathrm{SCH} 23390$ from those of amphetamine individually relative to saline injections (ie the summed deviation of SCH23390 + amphetamine). (c) D, receptor stimulation with low doses of SKF8 I297. A low dose $(0.1 \mathrm{mg} / \mathrm{kg})$ had no effect, whereas the $0.3 \mathrm{mg} / \mathrm{kg}$ dose increased the proportion of choices of the large/ risky lever in the middle two blocks. (d) D, receptor stimulation with a high dose of SKF8I297 (I.0 mg/kg) exerted biphasic effects. Proportion of choices of the large/risky lever decreased during the $50 \%$ block and increased on the $25 \%$ block.

$P<0.05, P<0.05$; Table 2). This interaction was attributable to the fact that treatment with SCH23390 + amphetamine did not alter latencies during the first two trial blocks, but increased response latencies on the 25 and $12.5 \%$ blocks compared to both the $0.50 \mathrm{mg} / \mathrm{kg}$ dose of amphetamine, as well as vehicle treatments. It is also notable that the disruption in performance during the first block by this dose of $\mathrm{SCH} 23390$ was reversed by amphetamine cotreatment. Amphetamine also increased response latencies compared to vehicle, but only on the $50 \%$ block. In addition to its effects on choice, SCH23390 also blocked the increase in locomotion induced by amphetamine $(\mathrm{F}(2,14)=22.45$, $P<0.01$; Table 2).

We conducted a separate analysis comparing the observed effects of SCH23390+ amphetamine to an 'expected' discounting curve. This was calculated by subtracting the effects of SCH23390 from those of amphetamine individually relative to saline injections. As can be seen in Figure $3 \mathrm{~b}$ (gray line), the summed deviation of the effects of SCH23390 and amphetamine generated a discounting curve that was significantly different from the observed effect of SCH23390 + amphetamine $(\mathrm{F}(1,7)=76.97, P<0.01)$. This suggests that the blockade of the effects of amphetamine on risky choice by $\mathrm{SCH} 23390$ is unlikely to be mediated by a simple additive effect of the two drugs (ie increased risky choice by amphetamine and risk aversion by SCH23390) canceling each other out. It should be pointed out that due to the length of testing of rats in this group, we did not administer a subthreshold dose of SCH23390 in conjunction with amphetamine. Therefore, the possibility that the effects $\mathrm{SCH} 23390$ + amphetamine were additive cannot be completely ruled out.

Stimulation with SKF81297. Rats in group D1/4 received three challenge doses of SKF81297 on separate test days. Analysis of the choice data revealed a significant dose $\times$ test day $\times$ block interaction $(\mathrm{F}(6,42)=3.76, P<0.01$, Dunnett's, $P<0.05$; Figures $3 \mathrm{c}$ and $\mathrm{d})$. The $0.1 \mathrm{mg} / \mathrm{kg}$ dose of SKF81297 had no effect on choice behavior. The $0.3 \mathrm{mg} / \mathrm{kg}$ dose induced a modest, but statistically significant $(P<0.05)$ increase in risky choice in the middle two blocks, whereas the $1.0 \mathrm{mg} / \mathrm{kg}$ dose exerted biphasic effects. On the $50 \%$ block, this dose decreased risky choice, but on the subsequent $25 \%$ block, rats made significantly more choices 
of the large/risky lever compared to vehicle treatments (Figure 3d). The $1.0 \mathrm{mg} / \mathrm{kg}$ dose of SKF81297 increased omissions relative to saline $(\mathrm{F}(2,14)=15.38, \quad P<0.01$; Dunnett's, $P<0.05$; Table 2). Analysis of the latency data also revealed a dose $\times$ test day $\times$ block interaction $(\mathrm{F}(6,42)=3.42, P<0.01$, Dunnett's, $P<0.05$; Table 2) due to the effects of the $1.0 \mathrm{mg} / \mathrm{kg}$ dose of SKF81297 increasing response latencies compared to saline during the 100 and $50 \%$ trial blocks. Locomotion was also significantly increased by the $1.0 \mathrm{mg} / \mathrm{kg}$ dose of SKF81297 $(\mathrm{F}(2,14)=$ 4.48, $P<0.05$, Dunnett's, $P<0.05$; Table 2). Thus, increasing $\mathrm{D}_{1}$ receptor activity using a selective agonist increases risky choice, although these effects were not as pronounced as those induced by amphetamine.

\section{$\mathrm{D}_{\mathbf{2}}$ Receptor Compounds}

Blockade with eticlopride. Following drug tests with SCH23390, rats in group AMPH were retrained for 9 days and then administered two doses of eticlopride. The analysis revealed a significant main effect of test day with no significant interactions $(\mathrm{F}(1,7)=63.76, \quad P<0.01$; Figure 4a). On average across the two doses, eticlopride significantly decreased choice of the large/risky lever. The $0.03 \mathrm{mg} / \mathrm{kg}$ dose of eticlopride significantly increased trial omissions compared to saline $(\mathrm{F}(2,14)=28.89$, Dunnett's, $P<0.01$; Table 2) and reduced preference for the large/risky lever on the $100 \%$ trial block. In contrast, the $0.01 \mathrm{mg} / \mathrm{kg}$ dose of eticlopride that did not significantly increase omissions or induce an apparent decrease in preference for larger rewards on the $100 \%$ block, induced risk aversion, most prominently during the 50 and $25 \%$ blocks. The $0.03 \mathrm{mg} / \mathrm{kg}$ dose of eticlopride significantly increased response latencies compared to saline during the last three trial blocks, whereas the $0.01 \mathrm{mg} / \mathrm{kg}$ had no effect (dose $\times$ test day $\times$ block interaction $(\mathrm{F}(3,21)=6.24, P<0.01$, Dunnett's, $P<0.05$; Table 2). Both doses of eticlopride also induced a significant decrease in locomotor counts relative to saline $(\mathrm{F}(2,14)=5.37, P<0.05$; Table 2$)$.

Amphetamine +eticlopride. We then combined the $0.50 \mathrm{mg} / \mathrm{kg}$ dose of amphetamine with the $0.01 \mathrm{mg} / \mathrm{kg}$ dose of eticlopride. Analysis of the choice data revealed a significant test day $\times$ block interaction $(F(6,42)=2.32$, $P<0.05$, Dunnett's, $P<0.05$; Figure $4 \mathrm{~b}$ ). Amphetamine continued to be effective at increasing risky choice on the latter two trial blocks. Eticlopride + amphetamine attenuated the effects of amphetamine on the $25 \%$ trial block, though risky choice was significantly decreased on the $50 \%$ block compared to amphetamine and significantly elevated on the $12.5 \%$ trial block compared to vehicle. This drug combination had no effects on response latencies (all F's $<1.07, \mathrm{NS})$. Eticlopride also attenuated the locomotor effects of amphetamine $(\mathrm{F}(2,14)=30.33, P<0.01$; Table 2). Thus, blockade of $\mathrm{D}_{2}$ receptors attenuated the ability of amphetamine to increase risky choice, but these effects were not as pronounced as those induced by $\mathrm{D}_{1}$ antagonism.

Stimulation with bromocriptine. Rats in group D2/3 received two challenge doses of the $\mathrm{D}_{2}$ receptor agonist bromocriptine on separate test days. Analysis of the choice data revealed a significant dose $\times$ test day $\times$ block interaction

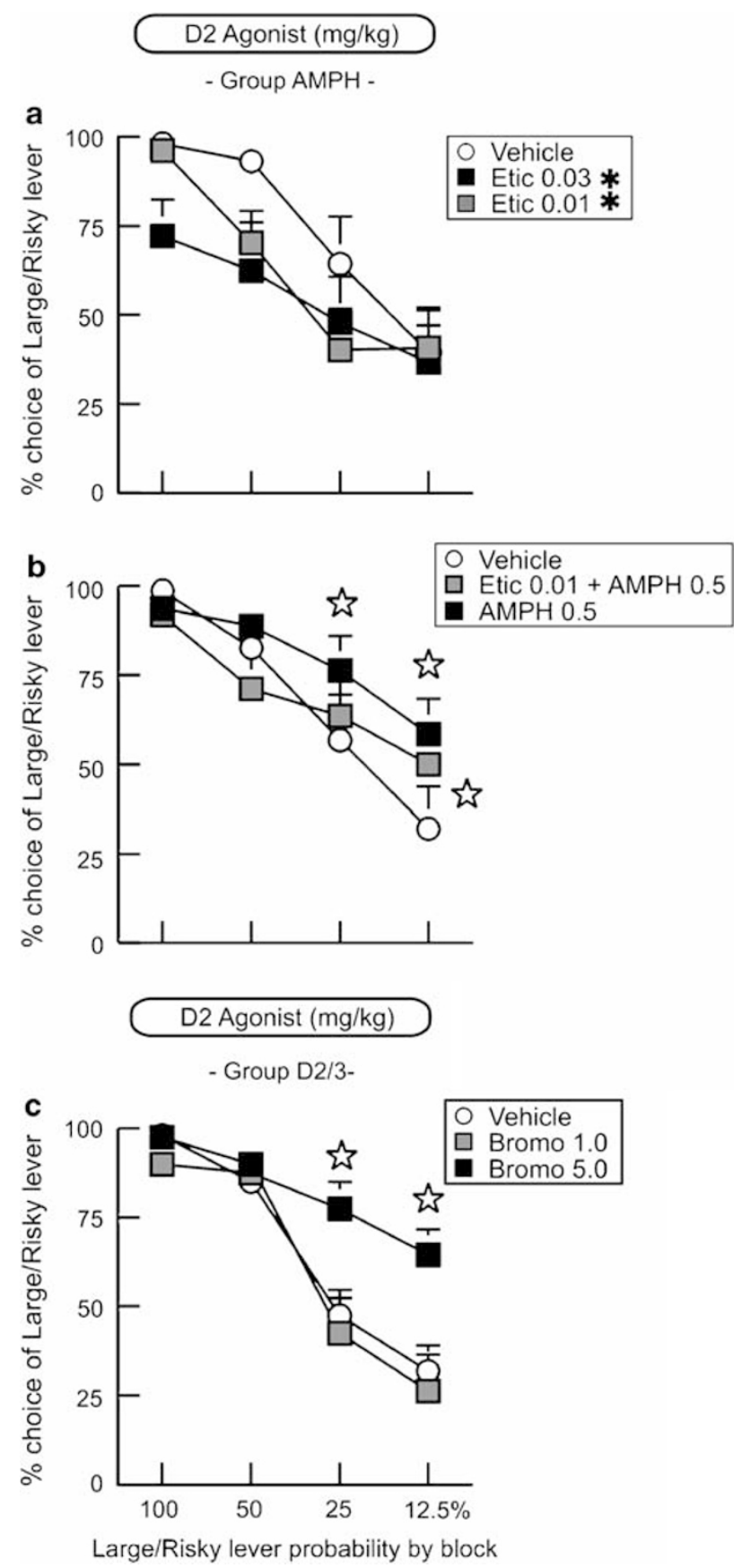

Figure 4 The effects of $D_{2}$ receptor manipulations on risk-based decision making. All conventions are the same as Figure 2. (a) $D_{2}$ receptor blockade with eticlopride (Etic). A higher dose $(0.03 \mathrm{mg} / \mathrm{kg})$ disrupted discrimination between small and large rewards, whereas a lower dose $(0.01 \mathrm{mg} / \mathrm{kg})$ that did not disrupt discrimination during the first block decreased the proportion of choices of the large/risky lever. Asterisks denote significant $(P<0.05)$ difference vs vehicle across all trial blocks. (b) Eticlopride + amphetamine. Blockade of $D_{2}$ receptors $(0.01 \mathrm{mg} / \mathrm{kg})$ before the administration of amphetamine attenuated the increased proportion of choices of the large/risky lever induced by amphetamine alone. (c) $D_{2}$ receptor stimulation with bromocriptine (Bromo). A low dose $(1.0 \mathrm{mg} / \mathrm{kg})$ had no effect, whereas a high dose $(5.0 \mathrm{mg} / \mathrm{kg})$ induced a dramatic increase in risky choice.

$(\mathrm{F}(3,21)=3.13, P<0.05$, Dunnett's, $P<0.05$; Figure $4 \mathrm{c})$. The $1.0 \mathrm{mg} / \mathrm{kg}$ dose did not significantly alter choice behavior. However, the $5.0 \mathrm{mg} / \mathrm{kg}$ dose induced a pronounced 
increase in risky choice during the 25 and $12.5 \%$ trial blocks. The increase in risky choice induced by the $5.0 \mathrm{mg} /$ $\mathrm{kg}$ dose was accompanied by an increase in response latencies during the 100, 25, and $12.5 \%$ trial blocks $(\mathrm{F}(3,21)=4.45, P<0.05$, Dunnett's, $P<0.05$; Table 2), as well as locomotor counts $(\mathrm{F}(2,14)=7.36, P<0.05$, Dunnett's, $P<0.05$; Table 2). Thus, stimulation of $\mathrm{D}_{2}$ receptors caused a strong shift in preference toward the larger, yet risky rewards.

\section{$D_{3}$ Receptor Compounds}

Blockade with nafadotride. Rats in group D3/4 were initially challenged with a $\mathrm{D}_{4}$ receptor antagonist (see below), after which they were subjected to tests with nafadotride. Blockade of $D_{3}$ receptors with the $2.0 \mathrm{mg} / \mathrm{kg}$ dose produced a moderate decrease in selection of the large/ risky lever, possibly due to blockade of $\mathrm{D}_{2}$ receptors (Levant and Vansell, 1997; Figure 5a). However, analysis of the choice data did not yield a significant main effect of test day nor any significant interactions with test day (all F's $<1$, NS). Similarly, nafadotride had no effect on response latencies (all F's <3.04, NS; Table 3). However, the $2.0 \mathrm{mg} /$ $\mathrm{kg}$ dose of this compound did decrease locomotor counts $(\mathrm{F}(3,21)=3.10, P<0.05$, Dunnett's, $P<0.05$; Table 3$)$, again consistent with the notion that higher doses of this compound blocks $\mathrm{D}_{2}$ as well as $\mathrm{D}_{3}$ receptors.

Amphetamine + nafadotride. Following challenges with nafadotride, rats in group D3/4 received injections of the $0.50 \mathrm{mg} / \mathrm{kg}$ dose combined with the $0.50 \mathrm{mg} / \mathrm{kg}$ dose of amphetamine. Analysis of the choice data produced a significant main effect of test day $(\mathrm{F}(2,14)=7.41, P<0.01)$ and test day $\times$ block interaction $(\mathrm{F}(6,42)=5.22, P<0.01$, Dunnett's, $P<0.05$; Figure $5 \mathrm{~b})$. Amphetamine again biased choice toward the large/risky lever. However, the effects of this challenge were not as robust as had been previously observed in these same rats (see below and Figure 6b). This was attributable primarily to one rat that made fewer choices of the large/risky lever during this amphetamine challenge, whereas the remaining seven rats in this group all continued to show an increased preference for this lever. Nevertheless, pretreatment with nafadotride actually potentiated the effects of amphetamine on risky choice, by significantly $(P<0.05)$ increasing choice of the large/risky lever compared to both vehicle and amphetamine on the 25 and $12.5 \%$ trial blocks. This effect was even more pronounced when a separate analysis was conducted the data obtained from the seven rats that increased risky choice following amphetamine challenge (see Supplementary
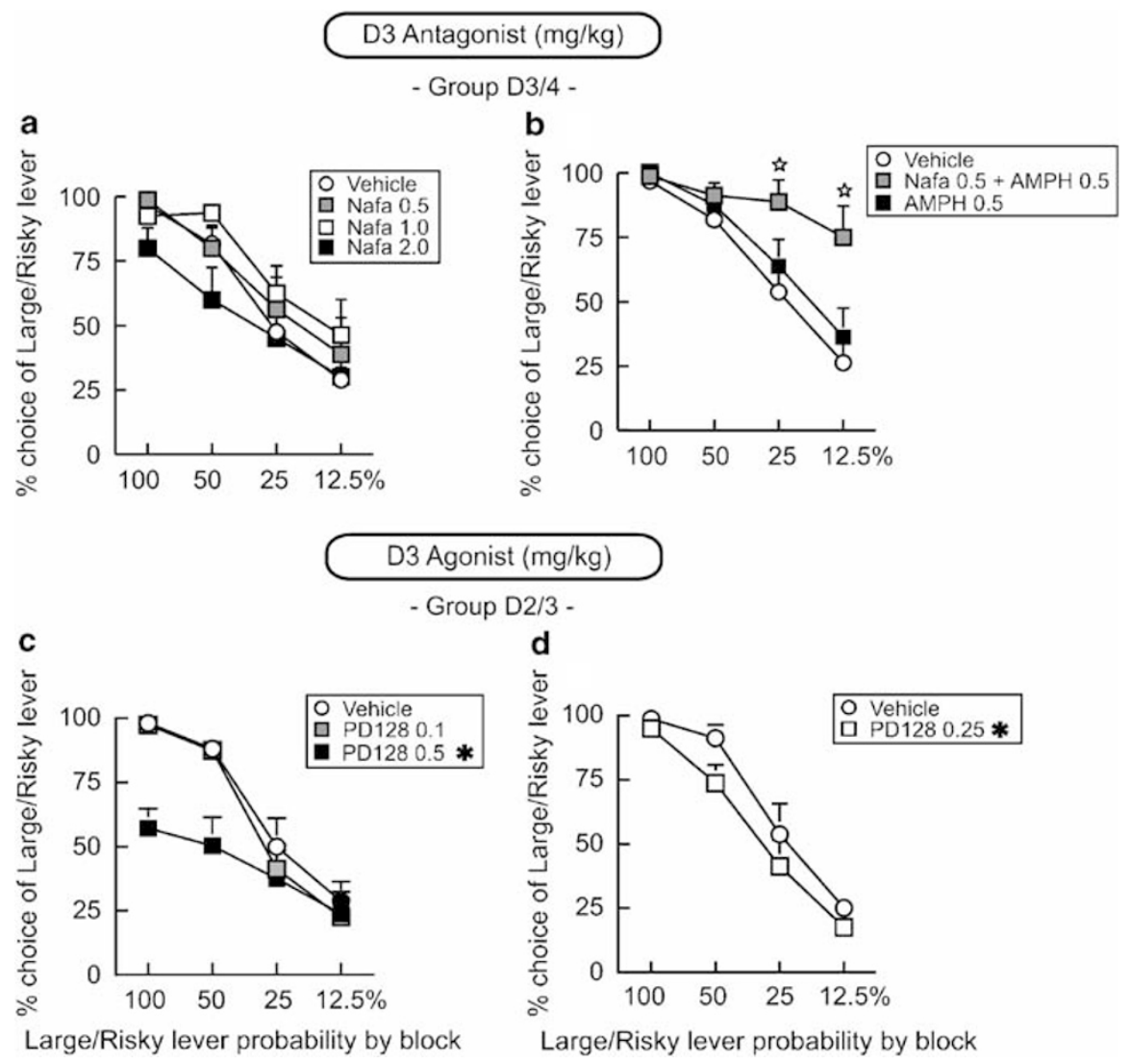

Figure 5 The effects of $D_{3}$ receptor manipulations on risk-based decision making. All conventions are the same as Figures 2 and 4 . (a) $D_{3}$ receptor blockade with nafadotride (Nafa). A high dose $(2.0 \mathrm{mg} / \mathrm{kg}$ ) disrupted discrimination between small and large rewards. Low and middle doses (0.50, I.0 mg/ $\mathrm{kg}$ ) that did not disrupt discrimination moderately increased the proportion of choices of the large/risky lever. (b) Nafadotride + amphetamine. Blockade of $\mathrm{D}_{3}$ receptors $\left(0.50 \mathrm{mg} / \mathrm{kg}\right.$ ) before the administration of amphetamine potentiated the increase in risky choice induced by amphetamine alone. (c) $\mathrm{D}_{3}$ receptor stimulation with low and high doses of PDI28,907. A low dose $(0.10 \mathrm{mg} / \mathrm{kg})$ did not affect choice behavior, whereas a high dose $(0.50 \mathrm{mg} / \mathrm{kg})$ disrupted discrimination between smaller and larger rewards during the 100\% block, and continued to reduce preference for the large/risky lever in subsequent blocks. (d) The middle dose of PD 128,907 $(0.25 \mathrm{mg} / \mathrm{kg})$ decreased the proportion of choices of the large/risky lever. 
Table 3 Response Latency, Locomotion, Trial Omissions for $\mathrm{D}_{3}$ and $\mathrm{D}_{4}$ receptor compounds and satiety tests

\begin{tabular}{|c|c|c|c|}
\hline Drug test & Latency (s) & Locomotion counts & Omissions \\
\hline \multicolumn{4}{|l|}{$D_{3}$ compounds } \\
\hline \multicolumn{4}{|l|}{ Nafadotride } \\
\hline vehicle & $0.49 \pm 0.02$ & $1773 \pm 179$ & \\
\hline $0.50 \mathrm{mg} / \mathrm{kg}$ & $0.43 \pm 0.03$ & $1750 \pm 225$ & \\
\hline $1.0 \mathrm{mg} / \mathrm{kg}$ & $0.46 \pm 0.02$ & $1530 \pm 203$ & \\
\hline \multicolumn{4}{|l|}{ Nafadotride+AMPH } \\
\hline Vehicle & $0.49 \pm 0.02$ & $1687 \pm 245$ & \\
\hline $\mathrm{AMPH} 0.50 \mathrm{mg} / \mathrm{kg}$ & $0.43 \pm 0.00$ & $2991 \pm 534^{\mathrm{a}}$ & \\
\hline Nafa $0.5 \mathrm{mg} / \mathrm{kg}+\mathrm{AMPH} 0.50 \mathrm{mg} / \mathrm{kg}$ & $0.48 \pm 0.01$ & $3562 \pm 465^{\mathrm{a}}$ & \\
\hline \multicolumn{4}{|l|}{ PDI28,907 } \\
\hline \multicolumn{4}{|l|}{$D_{4}$ compounds } \\
\hline \multicolumn{4}{|l|}{$\mathrm{L} 745,870$} \\
\hline Vehicle & $0.48 \pm 0.04$ & $1700 \pm 244$ & \\
\hline $0.50 \mathrm{mg} / \mathrm{kg}$ & $0.42 \pm 0.02$ & $|68| \pm 260$ & \\
\hline $1.0 \mathrm{mg} / \mathrm{kg}$ & $0.45 \pm 0.04$ & $1742 \pm 248$ & \\
\hline $5.0 \mathrm{mg} / \mathrm{kg}$ & $0.53 \pm 0.04$ & $167 \mid \pm 319$ & \\
\hline \multicolumn{4}{|l|}{ L745,870+AMPH } \\
\hline Vehicle & $0.49 \pm 0.03$ & $1777 \pm 216$ & \\
\hline AMPH $0.50 \mathrm{mg} / \mathrm{kg}$ & $0.46 \pm 0.01$ & $309| \pm 49|$ & \\
\hline Food restriction (control) & $0.61 \pm 0.04$ & $1254 \pm 102$ & $0.7 \pm 0.3$ \\
\hline Acute free feeding & $1.27 \pm 0.25^{\mathrm{a}}$ & $1136 \pm 95$ & $5 \pm 2^{\mathrm{a}}$ \\
\hline Long-term free feeding & $1.53 \pm 0.20^{\mathrm{a}}$ & $1072 \pm 46^{\mathrm{a}}$ & $9 \pm 2^{\mathrm{a}}$ \\
\hline
\end{tabular}

${ }^{a} P<0.05$ vs vehicle or control.

Figure 1). This drug combination did not affect response latencies (all F's $<1.12$, NS), but did increase locomotor counts compared to both vehicle and amphetamine tests $(\mathrm{F}(2,14)=21.38, P<0.01$, Tukey's, $P<0.05$; Table 3$)$. Thus, blockade of $\mathrm{D}_{3}$ receptors potentiates the ability of amphetamine to increase both risky choice and locomotor activity.

Stimulation with PD128,907. After tests with bromocriptine, rats in group D2/3 received separate challenges with the $\mathrm{D}_{3}$ agonist PD128,907. Analysis of the choice data revealed a significant test day $\times$ dose interaction $(F(2,14)=7.92$, $P<0.01$, Dunnett's, $P<0.05$; Figures $5 \mathrm{c}$ and d). The $0.1 \mathrm{mg} /$ $\mathrm{kg}$ dose did not affect choice. However, the $0.5 \mathrm{mg} / \mathrm{kg}$ dose induced a pronounced decrease in the preference for the large/risky lever. This effect was apparent during the $100 \%$ block, suggesting that this dose induced a general disruption in discrimination between different magnitudes of rewards. Yet, the intermediate dose $(0.25 \mathrm{mg} / \mathrm{kg})$ also produced a moderate, but significant $(P<0.05)$ decrease in the preference for the large/risky lever relative to vehicle treatments. Inspection of Figure $5 \mathrm{~d}$ reveals that the effects of this dose were most prominent during the 50 and $25 \%$ blocks, but were not apparent during the $100 \%$ block. The $0.50 \mathrm{mg} / \mathrm{kg}$ dose significantly increased response latencies $\quad(\mathrm{F}(2,14)=4.58, \quad P<0.05, \quad$ Dunnett's, $\quad P<0.05$; Table 3). Furthermore, both the 0.25 and $0.5 \mathrm{mg} / \mathrm{kg}$ dose induced a moderate decrease in locomotor counts, however, analysis of these data did not achieve statistical significance $(F(3,21)=2.46, P=0.09$; Table 3$)$. Viewed collectively, in contrast to the effects on $\mathrm{D}_{1}$ and $\mathrm{D}_{2}$ receptors, activation of $\mathrm{D}_{3}$ receptors with PD128,907 reduces preference for larger rewards, particularly when their delivery is uncertain. 


\section{D4 Antagonist $(\mathrm{mg} / \mathrm{kg})$}

- Group D3/4-
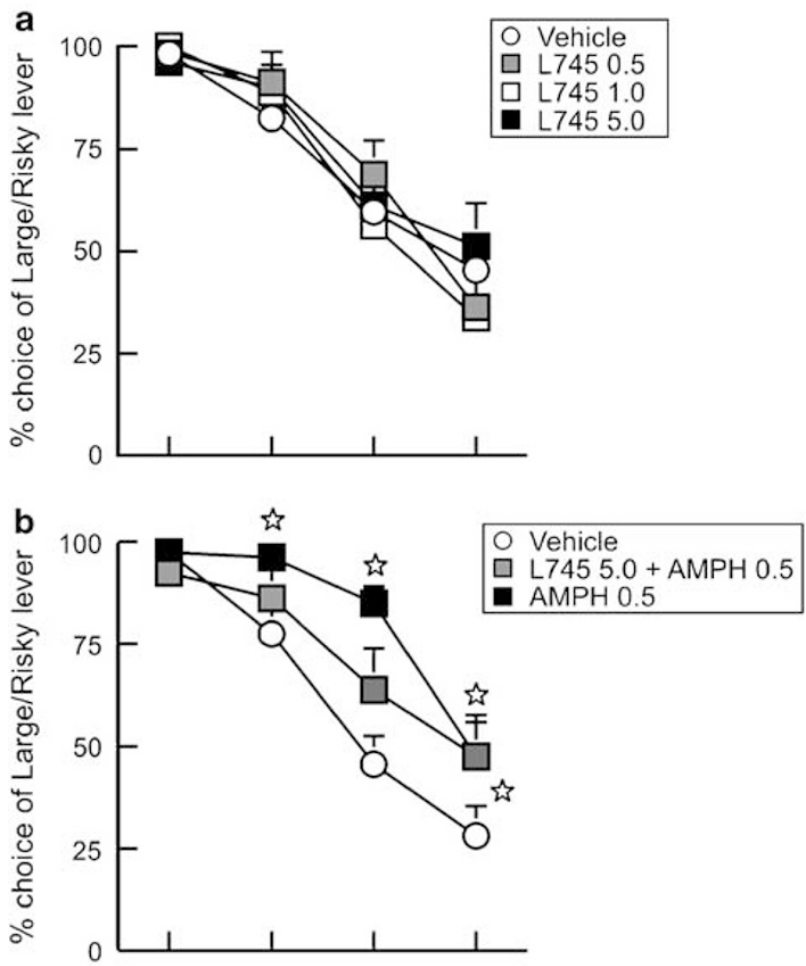

D4 Agonist (mg/kg)

- Group D1/4-

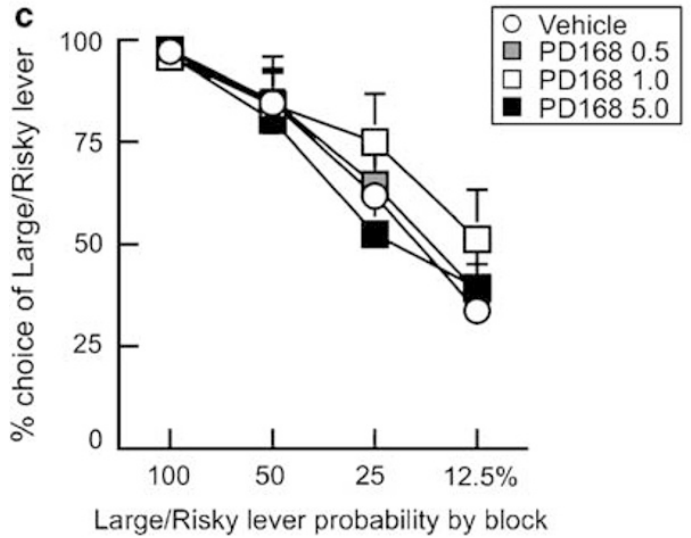

Figure 6 The effects of $D_{4}$ receptor manipulations on risk-based decision making. All conventions are the same as Figure 2. (a) $D_{4}$ receptor

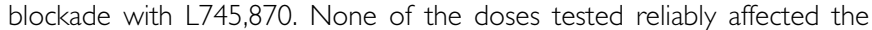
proportion of choices of the large/risky lever. (b) $L 745,870+$ amphetamine. Blockade of $\mathrm{D}_{4}$ receptors $(5.0 \mathrm{mg} / \mathrm{kg})$ before the administration of amphetamine attenuated the increased proportion of choices of the large/risky lever induced by amphetamine alone on the $25 \%$ trial block. (c) $D_{4}$ receptor stimulation with PD 168,077. None of the doses tested reliably affected the proportion of choices of the large/risky lever.

\section{$\mathrm{D}_{4}$ Receptor Compounds}

Blockade with $L 745,870$. As noted above, rats in group D3/4 were administered three doses of the $\mathrm{D}_{4}$ receptor antagonist L745,870 on separate test days after 30 days of training on the risk discounting task. Analysis of these data revealed that injections of this compound did not significantly affect choice using any of the three doses tested, as indicated by the lack of a significant main effect of test day $(\mathrm{F}(1,7)=0.39$, NS) or any other interactions (all F's $<3.49$, NS; Figure 6a). This compound did not affect response latencies or locomotion (all F's $<1.8$, NS; Table 3).

Amphetamine $+L 745,870$. Although blocking $\mathrm{D}_{4}$ receptors with L745,870 alone did not affect choice, this compound was somewhat effective at attenuating the effects of amphetamine. The analysis of the choice data indicated a significant main effect of test day $(\mathrm{F}(2,14)=6.09, P<0.05)$ and test day $\times$ block interaction $(\mathrm{F}(6,42)=2.51, P<0.05$, Dunnett's, $P<0.05$; Figure 6b). Amphetamine significantly increased the proportion of choices on the large/risky lever on the last three blocks, replicating the effect observed in group AMPH. On the 25\% block, the addition of L745,870 attenuated this increased preference for the large/risky lever, suggesting that $\mathrm{D}_{4}$ receptors may, at most, have a permissive role in mediating the effects of amphetamine on risky choice. Response latencies were not affected during this drug test (all F's $<2.83$, NS). L745,870 did not alter the increase in locomotor counts induced by amphetamine $(\mathrm{F}(2,14)=14.61, P<0.01$; Table 3$)$.

Stimulation with PD168,077. Rats in group D1/4 received drug challenges with the $\mathrm{D}_{4}$ receptor agonist PD168,077 following tests with the $\mathrm{D}_{1}$ agonist. Analysis of the choice data did not reveal a main effect of test day $(F(1,7)=3.37$, NS) or a dose $\times$ test day $\times$ block interaction $(F(6,42)=1.29$, NS; Figure 6c). PD168,077 also did not affect latencies to respond or locomotor counts (all F's $<1.91$, NS). Thus, $\mathrm{D}_{4}$ receptors appear to have a limited role in mediating risky choice.

\section{Satiety Manipulations}

After completion of all drug challenges, rats in groups D1/4 and $\mathrm{D} 2 / 3$ received daily training sessions for 3-5 days under food restriction, after which they were free-fed and continued to be trained for another 6 days. Analysis of the choice data revealed a significant day $\times$ block interaction $(\mathrm{F}(6,90)=6.00, P<0.01$, Dunnett's, $P<0.05$; Figure 7$)$. Compared to food restriction, acute and long-term free feeding reduced choice of the large/risky lever on the 100 and $50 \%$ trial blocks, but increased risky choice on the $12.5 \%$ block. Locomotor activity was not altered by acute free feeding, but long-term free feeding was associated with a statistically significant decrease in locomotor counts compared to food restriction $(\mathrm{F}(2,30)=3.93, P<0.05)$. In addition, both acute and long-term free feeding significantly increased response latencies during the latter trial blocks $(\mathrm{F}(6,90)=10.09, \quad P<0.01)$, as well as trial omissions $(\mathrm{F}(2,30)=13.55, \quad P<0.01$; Table 3$)$ compared to food restriction. Although the pattern of choice across the trial blocks was altered by free feeding (ie a flattening of the discounting curve), rats still displayed prominent discounting of the large/risky lever throughout the session, as the probability of obtaining the larger reward decreased over blocks. Thus, a decrease in primary motivation for food 
- Groups D1/4 + D2/3-

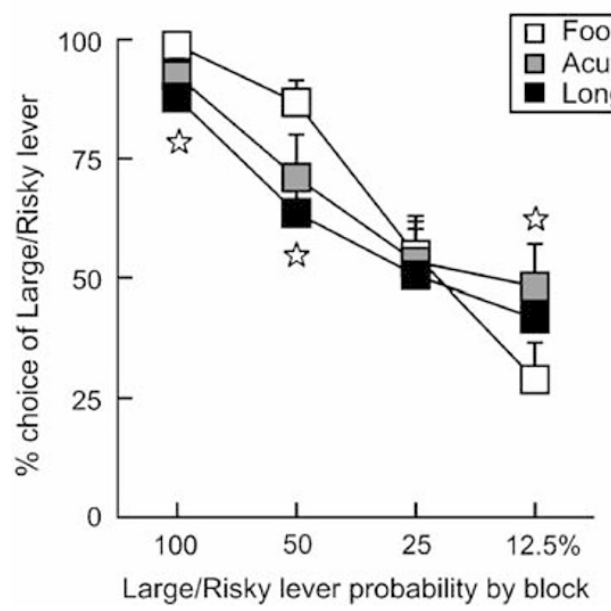

Figure 7 The effects of acute and long-term free feeding on risk-based decision making. Both acute access to food ad libitum (gray squares) and long-term free feeding (black squares) decreased the proportion of choices of the large/risky lever compared to performance under food restriction conditions (white squares) on the 100 and $50 \%$ trial blocks, but increased choice of the large/risky lever during the 12.5\% trial block.

induced by free feeding does alter risky choice using this assay, with rats adopting a suboptimal pattern of choice compared to performance under food restriction.

\section{DISCUSSION}

Here we report that DA has a critical role in mediating riskbased decision making, with different receptor subtypes having opposing roles in the mediation of risky choice. Amphetamine produces a reliable and robust increase in the preference for larger, yet probabilistic rewards, which is either blocked or attenuated by $\mathrm{D}_{1}$, or $\mathrm{D}_{2}$, receptor antagonists. In contrast, a $\mathrm{D}_{3}$ antagonist potentiated the effects of amphetamine. Conversely, blocking $\mathrm{D}_{1}$ or $\mathrm{D}_{2}$ receptors reduces preference for the large/risky lever. Furthermore, administration of receptor selective $\mathrm{D}_{1}$ or $\mathrm{D}_{2}$ agonists also increases risky choice, whereas $\mathrm{D}_{3}$ receptor agonists reduced choice of the large/risky lever. Collectively, these data indicate that increased $\mathrm{D}_{1}$ or $\mathrm{D}_{2}$ receptor activity biases choice behavior toward riskier response options associated with larger rewards, whereas $\mathrm{D}_{3}$ receptors have a opposing role in modulating this form of decision making.

\section{Amphetamine-Induced Increases in Risky Choice}

To our knowledge, this is the first study to systematically assess the effects of amphetamine on risk-based decision making and demonstrate an increase in risky choice. It is notable that the effects of amphetamine on other forms of decision making have been studied in some detail. Similar doses of amphetamine to those used in the present study increase preference for larger, delayed rewards (Cardinal et al, 2000; Wade et al, 2000; van Gaalen et al, 2006), although in other instances, these treatments can cause the opposite effects (Evenden and Ryan, 1996; Cardinal et al, 2000). Amphetamine also exerts dose-dependent, biphasic effects on effort discounting; low doses increase, whereas higher doses decrease the tendency for rats to work for a larger reward. (Floresco et al, 2008). In the current study, all doses of amphetamine increased choice of the lever associated with the larger, yet probabilistic reward. From these findings, it is apparent that amphetamine can exert differential effects on certain forms of cost/benefit decision making, depending on the particular type of cost animals must evaluate.

A previous study reported that amphetamine increases preference for a larger, probabilistic reinforcer but only in two rats whose baseline choice of the probabilistic lever was low (ie 20\%; Kaminski and Ator, 2001). Rats whose baseline choice of the probabilistic lever was considered high ( $>50 \%$ ) decreased their preference for the risky lever after an amphetamine challenge, an effect that was dependent on the intertrial interval length. Despite a small sample, these data imply that there may be individual differences in baseline patterns of risky choice, which may contribute to different behavioral responses to amphetamine. Note that in the present study, we also observed individual variability in baseline risky choice, yet here, amphetamine increased preference for the large/risky lever in all rats of each group tested. Indeed, we observed a positive correlation between baseline levels of risky choice and sensitivity to the locomotor effects of amphetamine (Supplementary Figure 2), suggesting that animals that are normally 'risky' may have a predisposed sensitivity to increases in DA transmission.

The effect of amphetamine on risk-based decision making appears to be attributable primarily to alterations in DA transmission, as pretreatment with DA antagonists significantly blunted the risk-promoting effects of amphetamine. In particular, the $D_{1}$ antagonist blocked the ability of amphetamine to increase risky choice, whereas $D_{2}$ and $D_{4}$ antagonists attenuated these effects. Although disruption of other monoamine systems (eg serotonin) do not seem to disrupt probabilistic discounting (Mobini et al, 2000), the possibility that the effects of amphetamine may be mediated in part by actions on other neurotransmitters cannot be completely excluded. However, the fact that $D_{1}$ or $D_{2}$ receptor agonists also increased risky choice further supports the notion that increases in DA are a major contribution to the effects of amphetamine.

\section{$D_{1}$ and $D_{2}$ Receptors Promote Risky Choice}

Blocking $\mathrm{D}_{1}$ or $\mathrm{D}_{2}$ receptors, at doses that did not disrupt reward sensitivity induced risk aversion. Conversely, selective activation of these receptors increased risky choice. We also observed biphasic effects with the $1.0 \mathrm{mg} /$ $\mathrm{kg}$ dose of SKF81297, such that rats were risk averse when the probability of the large reward was $50 \%$ and risk prone when the probability was $25 \%$. These effects are particularly interesting given the vast literature on the effects of $D_{1}$ receptor stimulation and other types of cognition that often takes the form of an 'inverted U-shaped' function, where reductions or increases in this activity can impair cognitive abilities such as working memory (Arnsten 1997; Zahrt et al, 1997; Floresco and Phillips, 2001; Chudasama and Robbins, 2004; Floresco and Magyar, 2006; Williams and Castner, 2006). The fact that a $D_{1}$ agonist promoted risk aversion when the probability of the larger reward was the 
most uncertain (ie $50 \%$ block) is notable, given that DA neurons display the greatest firing rate when the probability of reward is the most uncertain (Fiorillo et al, 2003). Therefore, it is plausible that endogenous DA activity may peak during those particular trials so that excessive exogenous stimulation of $D_{1}$ receptors may impair decision making.

Although $D_{1}$ receptor blockade was more effective at attenuating the effects of amphetamine compared to $D_{2}$ receptor antagonism, stimulation of $\mathrm{D}_{2}$ receptors with bromocriptine induced a substantially greater increase in risky choice across the latter three trial blocks. This was different from the effects of the $D_{1}$ agonist, which only increased risky choice in the middle two trial blocks, where the probability or overall amount of reward that could be obtained was most uncertain. The effect of bromocriptine is particularly intriguing given that this compound, like other DA receptor agonists used to treat parkinsonian symptoms, has been linked to the emergence of pathological gambling (Gallagher et al, 2007). In contrast, $\mathrm{D}_{4}$ receptor agonists or antagonists by themselves did not reliably affect choice. Thus, even though the $D_{4}$ receptor gene has been linked to ADHD (Li et al, 2006), indices of novelty seeking (Benjamin et al, 1996), and pathological gambling (Pérez de Castro et al, 1997), our data suggest that $\mathrm{D}_{4}$ receptor activity does not make a critical contribution to evaluations about risk and rewards. Rather, these receptors may be more important for judgments about the aversive consequences of certain actions (Shah et al, 2004; Floresco and Magyar, 2006).

\section{Opposing Roles of $\mathrm{D}_{2} V s \mathrm{D}_{3}$ Receptors on Risk-Based Decision Making}

Compared to the effects of $\mathrm{D}_{2}$ receptor stimulation, the $\mathrm{D}_{3}$ preferring agonist PD128,907 exerted the opposite effects on choice, decreasing preference for the lever associated with larger rewards, particularly during trial blocks where the delivery of reward was probabilistic. This $\mathrm{D}_{3}$ compound can inhibit endogenous DA release and DA neuron firing (Gobert et al, 1996; Millan et al, 2000), which would reduce activity at $D_{1}$ and $D_{2}$ receptors and potentially contribute to its effects on choice behavior. Conversely, the $\mathrm{D}_{3}$ antagonist nafadotride potentiated amphetamine-induced increases in risky choice, further supporting the notion that $\mathrm{D}_{3}$ receptors work in opposition to $\mathrm{D}_{1}$ and $\mathrm{D}_{2}$ receptors in the modulation of risk-based decision making. These results complement an emerging literature demonstrating opposing roles for $\mathrm{D}_{3}$ vs $\mathrm{D}_{2}$ or $\mathrm{D}_{1}$ receptors in delay discounting (van den Bergh et al, 2006; van Gaalen et al, 2006), memory consolidation (Sigala et al, 1997), yawning (Collins et al, 2005), and locomotion (Millan et al, 2004). It is interesting to point out that our findings showing certain doses of a $\mathrm{D}_{3}$ agonist reduce preference for larger, probabilistic rewards are contrary to the notion that the emergence of pathological gambling tendencies induced by parkinsonian mediations, such as pramipexole, are due to excessive stimulation of $\mathrm{D}_{3}$ receptors (Dodd et al, 2005; Szarfman et al, 2006). The present findings would indicate that supranormal activation of $\mathrm{D}_{2}$ receptors is more likely to promote risky choice or gambling behaviors.

\section{Mechanisms Underlying Changes in Risky Choice Induced by DA Manipulations}

One argument for the increase in risky choice induced by augmented DA activity may be that these treatments altered perceptions of differences in reward magnitude. Indeed, changing the magnitude of reinforcers affects choice of probabilistic rewards (Mazur, 1988). However, we find this to be an unlikely explanation because similar doses of amphetamine decrease, rather than increase preference for larger rewards using other cost/benefit discounting tasks where the cost increased over a session (Evenden and Ryan, 1996; Cardinal et al, 2000; Floresco et al, 2008). This finding also argues against the notion that DA agonists impair flexibility, with animals perseverating on the alternative associated with the larger reward. Tests using increasing, rather than decreasing probabilities within a session would address this question directly. In this regard, it is notable that on a similar task, nucleus accumbens lesions induce a risk-averse pattern of choice regardless of whether the odds of receiving the larger reward increase or decrease through a session (Cardinal and Howes, 2005). It is also important to note that similar doses of amphetamine enhance switching behaviors assessed with other paradigms (Evenden and Robbins, 1985; Weiner, 1990). The risk-aversive effects reported here are also unlikely to be attributable to alterations in perceived reward magnitude, because lower doses only decreased preference for the large/risky lever during trial blocks where delivery of the large reward was probabilistic. In addition, DA antagonists do not alter perceived quantity of food using a psychophysical procedure (Martin-Iverson et al, 1987).

Both acute and long-term free feeding produced similar results: animals were risk averse on the first two blocks, similar to food restriction on the third block, and risk prone on the last block (Figure 7). This particular pattern of choice is actually the most disadvantageous strategy to maximize reward, indicating that motivation is an important factor in optimal decision making assessed in this manner. The fact that none of the compounds used in the present study induced this pattern of choice indicates that these pharmacological effects cannot be attributed to changes in primary motivational factors or satiety.

It has been proposed that the underlying processes that mediate of discounting of probabilistic rewards may be the same as those that mediate delay discounting (Rachlin et al, 1991; Mazur, 1997; Richards et al, 1999; Ostaszewski and Karzel, 2002; Green and Myerson, 2004). Thus, alterations in decision making reported here may be attributed to alterations in tolerance to wait for a larger reward. Indeed, pharmacological manipulations of DA activity alter impulsive choice in delay discounting tasks (Evenden and Ryan, 1996; Cardinal et al, 2000; Wade et al, 2000; van Gaalen et al, 2006; Floresco et al, 2008). However, there is evidence that these types of decisions may, in fact, be dissociable. Intact rats differentially alter their preference for larger rewards associated with increasing delays or risk (Adriani and Laviola, 2006). After extended training, rats shift to choosing a small/immediate reward $v s$ a larger/ delayed reward as the delay increases. Yet, rats persistently opt for larger, probabilistic rewards, even when the probability is very low; an effect that was maintained when 
the delay to reward was similar in both tasks. This may be related to the control an animal has, whereby waiting for an unpredictable, large reward may be more appealing than always waiting at a fixed delay. Furthermore, comparisons between stimulant abusers and pathological gamblers have revealed dissociable impairments on risk and delay discounting tasks (Vuchinich and Calamas, 1997; Bickel et al, 1999; Holt et al 2003). Similarly, the tendencies for healthy individuals to make rapid, impulsive choices and bet large amounts of money on uncertain outcomes have been proposed to be mediated by independent processes (Deakin et al 2004).

Further evidence for dissociable mechanisms underlying delay and risk discounting comes from neurochemical studies. Amphetamine differentially affects both tasks with regard to advantageous patterns of choice. Administration of amphetamine at doses similar to those used in the present study make rats less impulsive on delay discounting tasks (advantageous; Cardinal et al, 2000; Wade et al, 2000; van Gaalen et al, 2006; Floresco et al, 2008), whereas it increases risky choice (which can be disadvantageous), although under some circumstances, these treatments increase impulsive choice (Evenden and Ryan, 1996; Cardinal et al, 2000). Notably, the $\mathrm{D}_{2}$ antagonist eticlopride decreased risky choice in the present study, yet similar doses of this drug do not affect delay discounting (van Gaalen et al, 2006). Furthermore, lesions of the serotonergic pathway in rats increases delay discounting but have no effect on probabilistic discounting (Mobini et al, 2000). Collectively, these studies suggest that delay and probabilistic discounting are separable processes whose underlying neural mechanisms can be studied independently.

In light of the above-mentioned considerations, we propose that a more likely explanation for the ability of dopaminergic manipulations to influence risky choice may be that these drugs interfere with processes related to the calculation of probabilities of receiving a particular reward. In the first trial block, animals correctly choose between two certain options; the smaller and larger reinforcer. However, when the large reinforcer becomes uncertain (latter three trial blocks), altering DA activity severely disrupts the animal's ability to make the optimal choice. Blocking or stimulating $D_{1} / D_{2}$ receptors resulted in rats behaving as if the probability of an uncertain, large reward was either less or more likely than it actually was, respectively. Therefore, increases or decreases in DA transmission may hamper calculations about the relative risks associated a particular choice, resulting in an over- or underestimation of the likelihood of obtaining rewards delivered in a probabilistic manner. This notion is supported by the finding that DA neurons display differential patterns of firing, depending on the expected probability of obtaining a reward, with the greatest increase in firing occurring when reward probability is the most uncertain (Fiorillo et al, 2003). This complements findings that midbrain DA neural activity is increased when a cue is presented that is associated with an unexpected or greater than expected reward (Schultz and Dickinson 2000; Schultz 2006). Midbrain DA neurons also respond to errors in prediction, suggesting that DA activity may contribute to a 'teaching signal' about recent errors in predicting reward, and thus, aid the animal in learning the probability of future reward
(Schultz and Dickinson, 2000). In the task used in the present study, DA may function to update the representation of reward probability within each trial block. It has been suggested that DA activity may have a reactive or opportunistic role in adapting baseline decision-making processes to the current needs of the organism by bridging internal physiological and psychological states with executive processes (Phillips et al, 2007). In the context of the present study, when rats are hungry, changes in DA transmission could influence decisions about whether to take a risk to obtain a larger amount of food.

\section{Clinical Implications}

Impaired decision making related to risks and rewards have been associated with a number of neuropsychiatric disorders that have been linked to the DA system. Our findings that amphetamine promotes an increase in risky choice bears a striking resemblance to the behavior of chronic stimulant abusers, who make disadvantageous, risk-prone patterns of choice on a number of tasks assessing risk-related decision making (Rogers et al, 1999; Bechara et al, 2001). In a similar vein, DA receptor agonist therapy for Parkinson's disease has been linked to the emergence of pathological gambling tendencies occurring in a subpopulation of these patients. The fact that antiparkinsonian agents like bromocriptine increase risky decision making would suggest that the emergence of pathological gambling in patients on these mediations may be related to overstimulation of $\mathrm{D}_{2}$ receptors. In this regard, the specific DA terminal regions where these drugs may be acting to affect risk-based decision making remains unclear. One candidate region is the nucleus accumbens, as lesions of this structure induce risk aversion using a task similar to that used here (Cardinal and Howes, 2005). Alternatively, perturbations in DA transmission in the medial and orbital prefrontal cortex may also alter risk/reward judgments, given that damage to these regions alters risk-based decision making in both humans and animals (Bechara et al, 1994, 1999; Rogers et al, 1999; Mobini et al, 2002; Pais-Vieira et al, 2007; Clark et al, 2008). Elucidation of the specific dopaminergic circuits that mediate this form of decision making is a current topic of investigation in our laboratory.

\section{ACKNOWLEDGEMENTS}

This work was supported by an operating grant from the Canadian Institutes of Health Research and a Pilot Project Grant from Parkinson's Society Canada to SBF. JRSO is the recipient of scholarships from the Natural Sciences and Engineering Research Council of Canada and the Michael Smith Foundation for Health Research. SBF is a CIHR New Investigator, a Michael Smith Senior Scholar, and a recipient of a National Alliance for Research on Schizophrenia and Depression Young Investigator Award.

\section{DISCLOSURE/CONFLICTS OF INTEREST}

None. 


\section{REFERENCES}

Adriani W, Laviola G (2006). Delay aversion but preference for large and rare rewards in two choice tasks: implications for the measurement of self-control parameters. BMC Neurosci 7: 52, doi: $10.1186 / 1471-2202-7-52$.

Arnsten AF (1997). Catecholamine regulation of the prefrontal cortex. J Psychopharmacol 11: 151-162.

Bechara A, Damasio AR, Damasio H, Anderson SW (1994). Insensitivity to future consequences following damage to human prefrontal cortex. Cognition 50: 7-15.

Bechara A, Damasio H, Damasio AR, Lee GP (1999). Different contributions of the human amygdala and ventromedial prefrontal cortex to decision-making. J Neurosci 19: 5473-5481.

Bechara A, Dolan S, Denburg N, Hindes A, Anderson SW, Nathan PE (2001). Decision-making deficits, linked to a dysfunctional ventromedial prefrontal cortex, revealed in alcohol and stimulant abusers. Neuropsychologia 39: 376-389.

Benjamin J, Li L, Patterson C, Greenberg BD, Murphy DL, Hamer DH (1996). Population and familial association between the D4 dopamine receptor gene and measures of novelty seeking. Nat Genet 12: 81-84.

Bergh C, Eklund T, Södersten P, Nordin C (1997). Altered dopamine function in pathological gambling. Psychol Med 27: 473-475.

Bickel W, Odum A, Madden G (1999). Impulsivity and cigarette smoking: delay discounting in current, never, and ex-smokers. Psychopharmacology 146: 447-454.

Bitner RS, Nikkel AL, Otte S, Martino B, Barlow EH, Bhatia P et al (2006). Dopamine D4 receptor signaling in the rat paraventricular hypothalamic nucleus: evidence of natural coupling involving immediate early gene induction and mitogen activated protein kinase phosphorylation. Neuropharmacology 50: 521-531.

Bristow LJ, Cook GP, Gay JC, Kulagowski JJ, Landon L, Murray F et al (1996). The behavioural and neurochemical profile of the putative dopamine D3 receptor agonist, (+)-PD128907, in the rat. Neuropharmacology 35: 285-294.

Browman KE, Curzon P, Pan JB, Molesky AL, Komater VA, Decker MW et al (2005). A-412997, a selective dopamine D4 agonist, improves cognitive performance in rats. Pharmacol Biochem Behav 82: 148-155.

Cardinal RN, Howes NJ (2005). Effects of lesions of the nucleus accumbens core on choice between small certain rewards and large uncertain rewards in rats. BMC Neurosci 6: 37 (originally published online 28 May 2005, doi:10.1186/1471-2202-6-37).

Cardinal RN, Robbins TW, Everitt BJ (2000). The effects of d-amphetamine, chlordiazepoxide, alpha-flupenthixol and behavioral manipulations on choice of signaled and unsignalled delayed reinforcement in rats. Psychopharmacology 152: 362-375.

Chudasama Y, Robbins TW (2004). Dopaminergic modulation of visual attention and working memory in the rodent prefrontal cortex. Neuropsychopharmacology 29: 1628-1636.

Clark L, Bechara A, Damasio H, Aitken MR, Sahakian BJ, Robbins TW (2008). Differential effects of insular and ventromedial prefrontal cortex lesions on risky decision making. Brain 131: 1311-1322.

Collins GT, Witkin JM, Newman AH, Svensson KA, Grundt P, Cao $J$ et al (2005). Dopamine agonist-induced yawning in rats: a dopamine D3 receptor-mediated behavior. J Pharmacol Exp Ther 314: $310-319$.

Comings DE, Gade R, Wu S, Chiu C, Dietz G, Muhleman D et al (1997). Studies of the potential role of the dopamine D1 receptor gene in addictive behaviors. Mol Psychiatry 2: 44-56.

Comings DE, Gade-Andavolu R, Gonzalez N, Wu S, Muhleman D, Chen $C$ et al (2001). The additive effect of neurotransmitter genes in pathological gambling. Clin Genet 60: 107-116.
Comings DE, Rosenthal RJ, Lesieur HR, Rugle LJ, Muhleman D, Chiu C et al (1996). A study of the dopamine D2 receptor gene in pathological gambling. Pharmacogenetics 6: 223-234.

Cools R, Barker RA, Sahakian BJ, Robbins TW (2003). Dopa medication remediates cognitive inflexibility, but increases impulsivity in patients with Parkinson's disease. Neuropsychologia 41: 1431-1441.

Deakin J, Aitken M, Robbins T, Sahakian BJ (2004). Risk taking during decision-making in normal volunteers changes with age. JINS 10: 590-598.

Denk F, Walton ME, Jennings KA, Sharp T, Rushworth MFS, Bannerman DM (2005). Differential involvement of serotonin and dopamine systems in cost-benefit decisions about delay or effort. Psychopharmacology 179: 587-596.

Dodd ML, Klos KJ, Bower JH, Geda YE, Josephs KA, Ahlskog JE (2005). Pathological gambling caused by drugs used to treat Parkinson disease. Arch Neurol 62: 1377-1381.

Evenden JL, Robbins TW (1985). The effects of d-amphetamine, chlordiazepoxide and alpha-flupenthixol on food-reinforced tracking of a visual stimulus by rats. Psychopharmacology (Berl) 85: 361-366.

Evenden JL, Ryan CN (1996). The pharmacology of impulsive behaviour in rats: the effects of drugs on response choice with varying delays of reinforcement. Psychopharmacology (Berl) 128: 161-170.

Fiorillo CD, Tobler PN, Schultz W (2003). Discrete coding of reward probability and uncertainty by dopamine neurons. Science 299: 1898-1902.

Floresco SB, Magyar O (2006). Mesocortical dopamine modulation of executive functions: beyond working memory. Psychopharmacology 188: 567-585.

Floresco SB, Phillips AG (2001). Delay-dependent modulation of memory retrieval by infusion of a dopamine D1 agonist into the rat medial prefrontal cortex. Behav Neurosci 115: 934-939.

Floresco SB, Tse MTL, Ghods-Sharifi S (2008). Dopaminergic and glutamatergic regulation of effort-and delay-based decision making. Neuropsychopharmacology 33: 1966-1979.

Frank MJ, Samanta J, Moustafa AA, Sherman SJ (2007). Hold your horses: impulsivity, deep brain stimulation, and medication in parkinsonism. Science 318: 1309-1312.

Gallagher DA, O'Sullivan SS, Evans AH, Lees AJ, Schrag AS (2007). Pathological gambling in Parkinson's disease: risk factors and differences from dopamine dysregulation an analysis of published case series. Mov Disord 22: 1757-1763.

Garcia RF, Ordacgi L, Mendlowicz MV, de Freitas GR, Rosso AZ, Nazar BP et al (2007). Treatment of juvenile Parkinson disease and the recurrent emergence of pathologic gambling. Cogn Behav Neurol 20: 11-14.

Gleason SD, Witkin JM (2006). Effects of dopamine D1 receptor agonists in rats trained to discriminate dihydrexidine. Psychopharmacology (Berl) 186: 25-31.

Gobert A, Lejeune F, Rivet JM, Cistarelli L, Millan MJ (1996). Dopamine D3 (auto) receptors inhibit dopamine release in the frontal cortex of freely moving rats in vivo. J Neurochem 66: 2209-2212.

Green L, Myerson J (2004). A discounting framework for choice with delayed and probabilistic rewards. Psychol Bull 130: 769-792.

Griffon N, Diaz J, Levesque D, Soutel F, Schwartz JC, Sokoloff P et al (1995). Localization, regulation and role of the dopamine D3 receptor are distinct from those of the D2 receptor. Clin Neuropharmacol 18(Suppl 1): S130-S142.

Holt DD, Green L, Myerson J (2003). Is discounting impulsive? Evidence from temporal and probability discounting in gambling and non-gambling college students. Behav Processes 31: 355-367.

Hotte M, Naudon L, Jay TM (2005). Modulation of recognition and temporal order memory retrieval by dopamine D1 receptor in rats. Neurobiol Learn Mem 84: 85-92. 
Imamura A, Uitti RJ, Wszolek ZK (2006). Dopamine agonist therapy for Parkinson disease and pathological gambling. Parkinsonism Relat Disord 12: 506-508.

Kaminski BJ, Ator NA (2001). Behavioral and pharmacological variables affecting risky choice in rats. J Exp Anal Behav 75: 275-297.

Kelsey JE, Carlezon Jr WA (2002). Prior experience with bromocriptine in the home cage attenuates locomotor sensitization in rats. Behav Brain Res 134: 1-8.

Levant B, Vansell NR (1997). In vivo occupancy of D2 dopamine receptors by nafadotride. Neuropsychopharmacology 17: $67-71$.

Li D, Sham PC, Owen MJ, He L (2006). Meta-analysis shows significant association between dopamine system genes and attention deficit hyperactivity disorder (ADHD). Hum Mol Genet 15: 2276-2284.

Lu C, Bharmal A, Suchowersky O (2006). Gambling and Parkinson disease. Arch Neurol 63: 298.

Martin-Iverson MT, Wilkie D, Fibiger HC (1987). Effects of haloperidol and d-amphetamine on perceived quantity of food and tones. Psychopharmacology 93: 374-381.

Mazur JE (1988). Choice between small certain and large uncertain reinforcers. Anim Learn Behav 16: 199-205.

Mazur JE (1997). Choice, delay, probability, and conditioned reinforcement. Anim Learn Behav 25: 131-147.

Millan MJ, Gobert A, Newman-Tancredi A, Lejeune F, Cussac D, Rivet JM et al (2000). S33084, a novel, potent, selective, and competitive antagonist at dopamine D(3)-receptors: I. Receptorial, electrophysiological and neurochemical profile compared with GR218,231 and L741,626. J Pharmacol Exp Ther 293: $1048-1062$.

Millan MJ, Seguin L, Gobert A, Cussac D, Brocco M (2004). The role of dopamine D3 compared with D2 receptors in the control of locomotor activity: a combined behavioural and neurochemical analysis with novel, selective antagonists in rats. Psychopharmacology (Berl) 174: 341-357.

Mimura M, Oeda R, Kawamura M (2006). Impaired decisionmaking in Parkinson's disease. Parkinsonism Relat Disord 12: 169-175.

Mobini S, Body S, Ho MY, Bradshaw CM, Szabadi E, Deakin JF et al (2002). Effects of lesions of the orbitofrontal cortex on sensitivity to delayed and probabilistic reinforcement. Psychopharmacology 160: 290-298.

Mobini S, Chiang TJ, Ho MY, Bradshaw CM, Szabadi E (2000). Effects of central 5-hydroxytryptamine depletion on sensitivity to delayed and probabilistic reinforcement. Psychopharmacology 152: $390-397$.

Ostaszewski P, Karzel K (2002). Discounting of delayed and probabilistic losses of different amounts. Eur Psychol 7: 295-301.

Pais-Vieira M, Lima D, Galhardo V (2007). Orbitofrontal cortex lesions disrupt risk assessment in a novel serial decision-making task for rats. Neuroscience 145: 224-231.

Perachon S, Schwartz JC, Sokoloff P (1999). Functional potencies of new antiparkinsonian drugs at recombinant human dopamine D1, D2 and D3 receptors. Eur J Pharmacol 366: 293-300.

Pérez de Castro I, Ibáñez A, Sáiz-Ruiz J, Fernández-Piqueras J (1997). Genetic association study between pathological gambling and a functional DNA polymorphism at the D4 receptor. Pharmacogenetics 7: 345-348.

Phillips AG, Vacca G, Ahn S (2007). A top-down perspective on dopamine, motivation and memory. Pharmacol Biochem Behav 90: 236-249 (originally published online 26 Nov 2007, doi:10.1016/j.pbb.2007.10.014).

Quickfall J, Suchowersky O (2007). Pathological gambling associated with dopamine agonist use in restless legs syndrome. Parkinsonism Relat Disord 13: 535-536.
Rachlin H, Raineri A, Cross D (1991). Subjective probability and delay. J Exp Anal of Behav 55: 233-244.

Richards JB, Zhang L, Mitchell SH, de Wit H (1999). Delay or probability discounting in a model of impulsive behavior: effect of alcohol. J Exp Anal Behav 71: 121-143.

Rogers RD, Everitt BJ, Baldacchino A, Blackshaw AJ, Swainson R, Wynne $\mathrm{K}$ et al (1999). Dissociable deficits in the decisionmaking cognition of chronic amphetamine abusers, opiate abusers, patients with focal damage to prefrontal cortex, and tryptophan-depleted normal volunteers: evidence for monoaminergic mechanisms. Neuropsychopharmacology 20: 322-329.

Salamone JD, Wisniecki A, Carlson BB, Correa M (2001). Nucleus accumbens dopamine depletions make animals highly sensitive to high fixed ratio requirements but do not impair primary food reinforcement. Neuroscience 105: 863-870.

Schultz W (2006). Behavioral theories and the neurophysiology of reward. Annu Rev Psychol 57: 87-115.

Schultz W, Dickinson A (2000). Neuronal coding of prediction errors. Annu Rev Neurosci 23: 473-500.

Seedat S, Kesler S, Niehaus DJ, Stein DJ (2000). Pathological gambling behaviour: emergence secondary to treatment of Parkinson's disease with dopaminergic agents. Depress Anxiety 11: 185-186.

Seeman P, Van Tol HH (1993). Dopamine receptor pharmacology. Curr Opin Neurol Neurosurg 6: 602-608.

Sevy S, Hassoun Y, Bechara A, Yechiam E, Napolitano B, Burdick K et al (2006). Emotion-based decision making in healthy subjects: short-term effects of reducing dopamine levels. Psychopharmacology 188: 228-235.

Shah AA, Sjovold T, Treit D (2004). Selective antagonism of medial prefrontal cortex D4 receptors decreases fear-related behaviour in rats. Eur J Neurosci 19: 3393-3397.

Sigala S, Missale C, Spano P (1997). Opposite effects of dopamine D2 and D3 receptors on learning and memory in the rat. Eur J Pharmacol 336: 107-112.

Szarfman A, Doraiswamy PM, Tonning JM, Levine JG (2006). Association between pathologic gambling and parkinsonian therapy as detected in the food and drug administration adverse event database. Arch Neurol 63: 299-300.

van den Bergh FS, Bloemarts E, Groenink L, Olivier B, Oosting RS (2006). Delay aversion: effects of 7-OH-DPAT, 5-HT1A/1Breceptor stimulation and D-cycloserine. Pharmacol Biochem Behav 85: 736-743.

van Gaalen MM, van Koten R, Schoffelmeer ANM, Vanderschuren LJMJ (2006). Critical involvement of dopaminergic neurotransmission in impulsive decision making. Biol Psychiatry 60: 66-73.

Vuchinich RE, Calamas ML (1997). Does the repeated gambles procedure measure impulsivity in social drinkers? Exp Clin Psychopharmacol 5: 157-162.

Wade TR, de Wit H, Richards JB (2000). Effects of dopaminergic drugs on delayed reward as a measure of impulsive behavior in rats. Psychopharmacology 150: 90-101.

Weiner I (1990). Neural substrates of latent inhibition: the switching model. Psychol Bull 108: 443-461.

Williams GV, Castner SA (2006). Under the curve: critical issues for elucidating D1 receptor function in working memory. Neuroscience 139: 263-276.

Winstanley CA, Theobald DE, Dalley JW, Robbins TW (2005). Interactions between serotonin and dopamine in the control of impulsive choice in rats: therapeutic implications for impulse control disorders. Neuropsychopharmacology 30: 669-682.

Zack M, Poulos CS (2004). Amphetamine primes motivation to gamble and gambling-related semantic networks in problem gamblers. Neuropsychopharmacology 29: 195-207. 
Zahrt J, Taylor JR, Mathew RG, Arnsten AF (1997). Supranormal stimulation of D1 dopamine receptors in the rodent prefrontal cortex impairs spatial working memory performance. J Neurosci 17: $8528-8535$.
Zhang K, Grady CJ, Tsapakis EM, Andersen SL, Tarazi FI, Baldessarini RJ (2004). Regulation of working memory by dopamine D4 receptor in rats. Neuropsychopharmacology 29: 1648-1655.

Supplementary Information accompanies the paper on the Neuropsychopharmacology website (http://www.nature.com/npp) 